\title{
Discovery and structure-activity relationships of modified salicylanilides as cell permeable inhibitors of poly(ADP-ribose) glycohydrolase (PARG)
}

\author{
Jamin D. Steffen ${ }^{\dagger}$, Donna L. Coyle ${ }^{\dagger}$, Komath Damodaran ${ }^{\ddagger}$, Paul Beroza ${ }^{\ddagger}$, , and Myron K. \\ Jacobson ${ }^{\dagger,}$, \\ tDepartment of Pharmacology and Toxicology, College of Pharmacy and Arizona Cancer Center, \\ University of Arizona, Tucson, Arizona 85724 \\ ‡Telik, Inc., 700 Hansen Way, Palo Alto, CA 94304
}

\section{Abstract}

The metabolism of poly(ADP-ribose) (PAR) in response to DNA strand breaks, which involves the concerted activities of poly(ADP-ribose) polymerases (PARPs) and poly(ADP-ribose) glycohydrolase (PARG), modulates cell recovery or cell death depending upon the level of DNA damage. While PARP inhibitors show high promise in clinical trials due to their low toxicity and selectivity for BRCA related cancers, evaluation of the therapeutic potential of PARG is limited by the lack of well-validated cell permeable inhibitors. In this study, Target-related Affinity Profiling (TRAP), an alternative to high-throughput screening, was used to identify a number of drug-like compounds from several chemical classes that demonstrated PARG inhibition in the low-micromolar range. A number of analogs of one of the most active chemotypes were synthesized to explore structure-activity relationship (SAR) for that series. This led to the discovery of a putative pharmacophore for PARG inhibition that contains a modified salicylanilide structure. Interestingly, these compounds also inhibit PARP-1, indicating strong homology in the active sites of PARG and PARP-1, and raising a new challenge for development of PARG specific inhibitors. The cellular activity of a lead inhibitor was demonstrated by the inhibition of both PARP and PARG activity in squamous cell carcinoma cells, although preferential inhibition of PARG relative to PARP was observed. The ability of inhibitors to modulate PAR metabolism via simultaneous effects on PARPs and PARG may represent a new approach for therapeutic development.

\section{Keywords}

poly(ADP-ribose); poly(ADP-ribose) glycohydrolase; poly(ADP-ribose) polymerase; PARG; PARP; PAR; salicylanilide; structure-activity relationship; dual inhibition; NAD; TRAP

\section{Introduction}

Activation of poly(ADP-ribose) (PAR) metabolism is an immediate response to genotoxic stress that promotes cell recovery at low levels of damage and cell death at high levels. ${ }^{1,2}$ In response to DNA strand breaks, PAR synthesis is catalyzed from $\mathrm{NAD}^{+}$by poly(ADPribose) polymerases 1 and 2 (PARP-1/2) and PAR degradation is catalyzed by poly(ADP-

\footnotetext{
"Corresponding Author: Myron K. Jacobson, Ph.D., Arizona Cancer Center, Room 3985, University of Arizona, 1515 N. Campbell Ave., Tucson, AZ 85724., Telephone: (520) 626-5957., Fax: (520) 626-8657., mjacobson@ pharmacy.arizona.edu.

Present address: Elan Pharmaceuticals, 800 Gateway Blvd., South San Francisco, CA 94080
} 
ribose) glycohydrolase (PARG) ${ }^{3-5}$ Activation of PARPs-1/2 results in the rapid accumulation of large, multi-branched PAR $^{6}$ that covalently modifies PARP-1, histones, p53, and nuclear proteins involved in DNA repair. ${ }^{7}$ At higher levels of DNA damage, the coordinate activities of PARPs-1/2 and PARG can rapidly deplete the pool of cellular $\operatorname{NAD}(H)$, facilitating the release of mitochondrial proteins through signaling pathways that promote cell death. ${ }^{8,9}$

Enzymes involved in PAR synthesis are promising therapeutic targets with development focused on PARP-1, the main synthesizing enzyme of PAR with a well defined role in cell fate determination, ${ }^{10-12}$ although PARP-2 selective inhibitors have been reported. ${ }^{13}$ PARP inhibitors are very well tolerated and have shown much promise in late stage clinical trials adjunctive with chemotherapy for triple negative breast cancers and as monotherapy for BRCA1/2 cancers. ${ }^{14-16}$ Much less is known concerning the therapeutic potential of PARG. ${ }^{17}$ The lack of high-throughput screening methods, lack of a crystal structure, and lack of bioavailable inhibitors has limited the evaluation of PARG. Complete PARG knockouts in mice are embryonic lethal, ${ }^{18}$ but deletion of the nuclear isoform of PARG results in hypersensitivity to DNA alkylating agents and radiation, demonstrating the requirement of a close coordination between PARP and PARG activities for responses to DNA damage. ${ }^{19,20}$ RNA interference approaches have aimed to overcome some of the limitations associated with the gene manipulation, but have been limited by the inability to completely suppress PARG activity. ${ }^{21-23}$ However, PARG knockdown in combination with disruption of base excision repair has been shown to enhance the cytotoxicity of temozolomide. ${ }^{24}$ There are several reports of PARG inhibitors consisting of hydrolysable tannins, ${ }^{25-27}$ ethacridine, ${ }^{28}$ the ADP-ribose analogue ADP-(hydroxymethyl)-pyrrolidinediol (ADP-HPD), ${ }^{29-31}$ and N-bis-(3-phenyl-propyl)9-oxofluorene-2,7-diamide (GPI 16552). ${ }^{32}$ While these inhibitors have shown utility in-vitro, questions pertaining to potency, selectivity, and cell permeability remain. ${ }^{33-35}$

As an alternative to a high-throughput screening, we applied Target-related Affinity Profiling (TRAP) to identify the initial PARG inhibitors described in this report. ${ }^{36}$ TRAP technology characterizes a chemical library of small molecules by their binding affinities to a panel of proteins, which defines an "affinity fingerprint". Activity information for a set of compounds (e.g., $\mathrm{IC}_{50}$ values) is combined with the affinity fingerprints of the compound to construct a fingerprint-based model for bioactivity. This model is used to select additional compounds for testing. Screening proceeds in an iterative manner, with batches of $\sim 70$ compounds tested followed by computational model refinement at each iteration. Such iterative cycles of compound selection, experimental assay, and model refinement have shown success in identifying bioactive molecules across a number of therapeutic targets. ${ }^{36}$

\section{Chemistry}

The simplest route to obtain salicylanilides involves amide coupling between commercially available salicylic acids and anilines (Scheme 1). The substituted amines 3a-g were created by cross coupling selected nitrobenzenes with various phenols using $\mathrm{Cs}_{2} \mathrm{CO}_{3}$ as the base in excess ( 3 equiv.) at $90^{\circ} \mathrm{C}$, to obtain the substituted nitrobenzenes $\mathbf{2 a - g}$. These nitrated compounds were selectively reduced to amines $\mathbf{3 a - g}$ in the presence of excess stannous chloride $\left(\mathrm{SnCl}_{2}\right)$ in ethanol. Benzoic acids were converted to acid chlorides $5 \mathbf{a}-\mathbf{f}$ by addition of excess thionyl chloride $\left(\mathrm{SOCl}_{2}\right)$ under reflux. Hydroxyl methylation of 3,5dichlorosalicylic acid was carried out prior to thionyl chloride treatment, by refluxing with potassium carbonate and iodomethane in acetone to give 4 . The acid chlorides were coupled

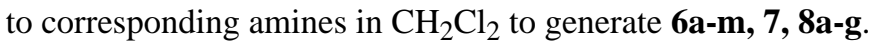


The Schiff base 9 was readily formed by the mixture of 3,5-dichloro-salicylaldehyde and substituted amine 3a in ethanol (Scheme 2). When this product was reacted with an excess of sodium cyanoborohydride (5 equiv.) in ethanol the Schiff base was selectively reduced to the amine 10. Mono-N-alkylation of 3a was achieved by refluxing the amine and potassium carbonate in acetone in the presence of iodomethane ( 5 equiv.). This reaction gave both the mono-N-methyl $\mathbf{1 1}$ and di-N-methyl products, which were separated by column chromatography. Compound $\mathbf{1 1}$ was coupled to $\mathbf{5 a}$ in $\mathrm{CH}_{2} \mathrm{Cl}_{2}$ to generate $\mathbf{1 2}$.

\section{Results and Discussion}

\section{A novel screening approach has led to the discovery of lead PARG inhibitors}

Target-related Affinity Profiling (TRAP) ${ }^{36}$ was used to search for lead inhibitors of PARG. For each round of screening, a hit was defined as a compound showing $70 \%$ inhibition of PARG at a defined concentration of test compound. In most cases, hits were subjected to dose-response evaluation to establish an approximate $\mathrm{IC}_{50}$ value. Four iterations of screening were completed and $\sim 70$ compounds were tested in each round. In total, 296 compounds were evaluated and $\sim 30$ compounds were identified with $\mathrm{IC}_{50}$ values below 100 $\mu \mathrm{M}$. Of these, the 24 best hits were screened a second time at $10 \mu \mathrm{M}$ and the 12 compounds with the highest degree of inhibition at this concentration were selected as the lead hits. The chemotype of the vast majority of these compounds was a substituted salicylanilide motif (Table 1). Common substitutions included the presence of a halide at two positions on the A ring of the salicylanilide (labeled A1 and A2) in 11 of the 12 hits, a chloro substitution on the $\mathrm{B}$ ring and an aromatic moiety attached to the $\mathrm{B}$ ring.

\section{SAR studies have defined a new pharmacophore for PARG inhibition}

To further explore the SAR relationships for PARG inhibition, we synthesized a series of additional salicylanilide analogs. Compound 1e was taken forward as the lead hit since it contained the greatest selectivity towards PARG over PARP-1. Initially $\mathbf{1 e}$ was modified by removal of the C-ring bromo-substitution 6a to remove a significant amount of molecular weight without losing significant activity. To determine the importance of the A ring hydroxyl and halo substitutions, a number of analogs were synthesized and tested for PARG inhibition (Table 2). Removal of the hydroxyl group at position A3 $\mathbf{6 b}$ resulted in loss of detectable inhibition of PARG, establishing this group as an important feature of the pharmacophore. Removal of both chloro substitutions $\mathbf{6 c}$ resulted in more than a 50-fold decrease in potency while removal of single chloro substitution $\mathbf{6 d}, \mathbf{6 e}$ decreased potency 510 fold. The requirement of a chloro substitution for inhibition led us to hypothesize that an acidic hydroxyl was a component of the pharmacophore rather than a hydrogen bond donor (HBD) hydroxyl. This hypothesis was supported by the observation that methylation of the hydroxyl group 6 f resulted in the loss of detectable PARG inhibition. In addition, PARG inhibition was retained when the acidic hydroxyl was replaced with a carboxylic acid $\mathbf{6 g}$. In total, these experiments demonstrate an acidic substitution at the position of the A ring hydroxyl as a key component of the PARG inhibition pharmacophore.

The next approach in defining the pharmacophore involved characterizing the involvement of the amide linker in PARG inhibition. Toward this end, a number of analogs were synthesized and tested for PARG inhibition properties (Table 3). The absence of the carbonyl group and amide hydrogen 9 resulted in loss of PARG inhibition. Removal of just the carbonyl group $\mathbf{1 0}$ also resulted in a loss of PARG inhibition. Methylation of the amide nitrogen 12 resulted in a 10-fold loss of PARG inhibition. These results argue that the pharmacophore involves the presence of a hydrogen bond acceptor (HBA), while the HBD is dispensable, but favorable for PARG inhibition. 
SAR experiments also examined the involvement of the $\mathrm{B}$ ring and $\mathrm{C}$ ring in PARG inhibition. A number of analogs were prepared that either eliminated or modified the $\mathrm{B}$ ring and/or $\mathrm{C}$ ring (Table 4). Complete elimination of the C-ring 8a resulted in a complete loss of PARG inhibition. When the hydroxyl was removed from the B-ring 8c, PARG inhibition returned although at low potency. It is likely the acidic nature of the hydroxyl on the B-ring in compound 8a is very unfavorable. When the Cring was deconstructed to a 4methylphenyl $\mathbf{6}$ and phenyl substitution $\mathbf{6 m}$, potency was decreased 2-fold and 5-fold respectively. Collectively these compounds indicate a large, hydrophobic substitution is favorable at the C-ring position

Elimination of the C-ring and B-ring 7 resulted in loss of detectable PARG inhibition. Replacement of the B-ring in the absence of any B-ring substitution $\mathbf{8 h}$ was still not enough to detect PARG inhibition. Only once the B-ring chloro-substitution $\mathbf{8 c}$ was replaced, was PARG inhibition detected again. Displacement of the chloro-substitution to the ortho- and para-positions of the B-ring $\mathbf{8 b}, \mathbf{8 d}$ resulted in a slight loss of potency. Switching out the chloro-substitution for a methyl substitution at all three positions 8e-g on the B-ring also resulted in a slight loss of potency. This indicated the B-ring substitution may serve to provide hydrophobicity rather than electron-withdrawing effects important for potency. To test this observation, substitutions were made at the B-ring in the presence of the C-ring. Replacing the chloro-substitution of the B-ring with substitutions of greater electronegativity $\mathbf{6 i}, \mathbf{6 j}$ resulted in nearly a 2 -fold loss in potency. When a methyl group was added instead $\mathbf{8 k}$, again only a slight loss of potency was observed. However, removal of a substitution at this position $\mathbf{8 h}$ resulted in a 3 -fold loss in potency. Taken together it is indicated that this Bring substitution slightly contributes to PARG inhibition due to its hydrophobicity rather than electron-withdrawing effects. These experiments define the B-ring and B-ring substitution as a necessary component of the pharmacophore, but potency is greatly enhanced by the presence of the C-ring. Figure 1 represents the pharmacophore for PARG inhibition derived from the SAR studies shown in Tables 2, 3, and 4.

It has been shown that salicylanilides form stable intermolecular hydrogen bonds, resulting in rigid, planar conformations. ${ }^{37}$ This is likely the case for compounds $\mathbf{6 c}$ and $\mathbf{6 f}$. However, in all other compounds that contain electron withdrawing groups at the 3 and 5 position of the A-ring, we predict the hydroxyl is predominantly ionized at physiological $\mathrm{pH}$. This ionized form may form an electron delocalized "pseudo-ring" with the amide nitrogen proton, or may simply be absent of intramolecular hydrogen bonding. While the exact conformation that effectively inhibits PARG is not currently known, it is likely that the negative charge plays a key role in inhibition, since the PAR substrate of PARG is a large, highly negatively charged polymer. It is possible the anionic hydroxyl (or carboxylic acid $\mathbf{6 g})$ mimics the negatively charged characteristic of PAR.

\section{PARG inhibitors also show inhibition of PARP-1}

We next examined the selectivity of compounds containing the PARG pharmacophore. Recent secondary structure predictions suggest that the active site domain of PARG has a high degree of homology to the ADP-ribosyl transferase domain of PARPs. ${ }^{38}$ Accordingly, we examined a number of the PARG inhibitors described in Tables 1 to 4 for effects on PARP-1. Each of these compounds also showed significant inhibition of PARP-1 (Table 5), although one compound 1e had a PARG selectivity of 15-fold. Also included in Table 5 are values taken from previous studies showing that the PARG inhibitor ADP-HPD does not inhibit PARP- $1^{30}$ and conversely that the PARP inhibitor benzamide does not inhibit PARG, ${ }^{39}$ demonstrating that selective inhibition of these two enzymes can be achieved. It should be noted that the PARG inhibitors did not inhibit the activity of other $\mathrm{NAD}^{+}$binding enzymes that bind via other $\mathrm{NAD}^{+}$binding motifs, SIRT1 and alcohol dehydrogenase (data not shown). The results shown in Table 5 point out a significant future challenge for the 
development of PARG specific inhibitors. On the other hand, they describe the discovery of a novel class of inhibitors with the potential to disrupt the coordination of PARP and PARG activities needed for cell responses to DNA damage.

\section{PARG inhibitors inhibit both PARP and PARG in intact cells but show a preference for PARG inhibition}

The efficacy of lead compounds was assessed by examining effects on PARP and PARG activity in a squamous cell carcinoma cell line (SCC-25). Effects on PARP activity in cells were examined by determination of $\mathrm{NAD}(\mathrm{H})$ depletion following treatment with the DNA damaging agent N-methyl-N-nitro-N-nitroso-guanidine (MNNG) as shown in Figure 2. When cells were treated for 30 min with MNNG, a dose-dependent decrease in $\mathrm{NAD}(\mathrm{H})$ content was observed (Figure 2A). The depletion of NAD(H) after $5 \mu \mathrm{g} / \mathrm{mL}$ MNNG treatment occurred for about 30 minutes, at which point consumption began to level off (Figure 2B). The complete inhibition of $\mathrm{NAD}(\mathrm{H})$ depletion by pre-incubation with the PARP inhibitor benzamide (Figure 2C) demonstrates that the depletion represents PARP activity in intact cells. Treatment of cells with active compounds $6 \mathbf{6}$ and $8 \mathbf{d}$ resulted in partial inhibition of $\mathrm{NAD}(\mathrm{H})$ consumption while treatment with inactive compounds $\mathbf{6 b}$ and 7 had minimal effect (Figure 2C). For all compounds, a concentration of $1 \mathrm{mM}$ was utilized for proof of principle of cell permeability. These results of Figure 2 demonstrate that $\mathbf{6 a}$ and 8d are causing PARP inhibition in intact cells. However, it is not possible to distinguish between direct inhibition of PARP activity and indirect inhibition due to increased automodification secondary to PARG inhibition.

To examine for effects on PARG activity in intact cells, PAR turnover experiments were completed. SCC-25 cells were first treated with MNNG to induce PAR formation. The addition of $1 \mathrm{mM}$ benzamide at 20 minutes inhibits further PARP activity, thus decreases in PAR content are due exclusively to PARG activity (Figure 3A). When 1mM 6a was added along with benzamide, PAR turnover was strongly inhibited following a short lag period (Figure 3A). These data further demonstrate that 6a effectively inhibits PARG in intact cells.

To examine the relative inhibition of $6 \mathbf{a}$ on PARP and PARG in SCC-25 cells, PAR content following MNNG treatment was examined in the presence and absence of $6 \mathbf{a}$. The activities of PARP and PARG are closely coordinated, thus the levels of PAR over time represent the relative activities of PARP and PARG. At the dose of MNNG used, PAR levels rapidly rise and reach a plateau at approximately 20 minutes and then slowly decline as PAR turnover continues but $\mathrm{NAD}(\mathrm{H})$ substrate is depleted (Figure $3 \mathrm{~B}$ ). When cells were pre-incubated with 6a, PAR accumulation at 10 min was increased approximately 3 -fold and PAR levels continued to increase gradually over the course of the experiment (Figure 3B). These results, demonstrate a preferential inhibition of PARG over PARP by $\mathbf{6 a}$. The same conclusion can be drawn from the results observed on PARP and PARG activity separately where 6a showed approximately $40 \%$ inhibition of PARP activity (Figure 2C) but nearly complete inhibition of PARG (Figure 3B) under the conditions of the experiments.

\section{Implications for therapeutic development}

The close coordination of PARP and PARG activities required for cellular responses to DNA damage and the results of clinical trials of PARP inhibitors for cancer treatment that report both low toxicity and promising efficacy ${ }^{14}$ dictate an evaluation of the therapeutic potential of PARG for cancer therapy. Additionally, the therapeutic potential of targeting PAR metabolism extends beyond cancer therapy to other pathological conditions that result from acute or chronic genotoxic stress. Upon DNA strand break recognition, PARP-1 activity is elevated nearly 500 -fold. ${ }^{40}$ High levels of DNA damage lead to concerted PARP and PARG activity that in turn results in rapid cellular depletion of NAD $(\mathrm{H})$ and release of 
mitochondrial components that promote cell death. ${ }^{41,}, 42$ Protective effects seen with PARP inhibition have therapeutic implications that include chronic heart disease, diabetic cardiovascular complications, circulatory shock, neurological diseases, ischemia/reperfusion injury and Parkinson's disease. ${ }^{43-45}$ PARP-1 activity is negatively regulated by PAR automodification and PARG is required for removing auto-modification. ${ }^{17}$ Thus, inhibition of PARG potentially represents an approach to prevent cell death by indirect inhibition of PARP activity.

Previously, a number of studies have reported positive effects in model systems of $\mathbf{1 3}$ (GPI 16552), a member of a group of symmetrically di-substituted aromatic PARG inhibitors developed by Guilford Pharmaceuticals, Inc. ${ }^{32,46,47}$ However, the cell permeability and selectivity of this class of inhibitors has not been reported. While we have demonstrated cellular activity of the lead PARG inhibitors described here, the observation that these inhibitors also inhibit PARP-1 in vitro and PARP activity in intact cells raises a new challenge for the development of PARG selective inhibitors. While the lead PARG inhibitors described here are not completely selective for PARG, the high degree of selectivity of inhibitors such as ADP-HPD for PARG ${ }^{30}$ provides evidence that future SAR studies have the potential to lead to highly selective and cell permeable PARG inhibitors. While more research is needed, the current PARG inhibitors show a more potent inhibition of PARG than PARP in intact cells (Figures 2 and 3). Indeed, while it is possible to determine effects on PARG activity in the absence of PARP activity (Figure 3A), inhibition of PARP activity in intact cells can be due to both direct inhibition of PARP and indirect inhibition of PARP as a result of increased automodification that inhibits PARP activity secondary to PARG inhibition. ${ }^{17}$

Our results, together with other work from our laboratory, ${ }^{38}$ make it likely that the active sites of PARG and PARP-1 (and likely other PARPs) share a high degree of similarity. Inhibition of PARG is not observed with PARP inhibitors such as benzamide that target the nicotinamide binding pocket of the NAD ${ }^{+}$binding site of PARPs,${ }^{39}$ as PARG most likely does not contain such a site. However, current highly potent PARP inhibitors are designed to reach outside of the nicotinamide binding pocket into the ADP-ribose region of the NAD ${ }^{+}$ site, as to gain favorable ADME properties and selectivity among PARP's. ${ }^{11}$ This added bulkiness of current PARP-1 inhibitors raises the possibility of PARG cross inhibition. PARG inhibition may not be a concern with highly potent PARP inhibitors specific for a particular cellular PARP but could possibly cause off target effects related to altered regulation of the coordinate function of a non-target PARP with its specific PARG partner. Consequently, the possible effect of current PARP clinical candidates on PARG would be of interest.

The molecules reported here represent only the initial steps in the development of molecules that will allow the evaluation of the therapeutic potential of targeting PARG. The current molecules provide proof of principle that cell permeable PARG inhibitors can be developed, but further studies will be needed to provide a definitive assessment of general toxicity and therapeutic potential of PARG inhibition.

\section{Conclusions}

The identification of several small molecule inhibitors of PARG has been obtained using a novel screening technology. Analogues based on these screening hits were designed to determine SAR that led to a modified salicylanilide pharmacophore for PARG inhibition. Analysis of the A-ring reveals an acidic hydroxyl as a key feature necessary for PARG inhibition. Further analysis of the amide linker reveals that a HBD is essential for PARG inhibition and a HBA is favorable for PARG inhibition. A Bring is required for inhibition 
and a hydrophobic substituent on the B-ring is highly favorable. The Cring contributes greatly to potency, even though the extra size is not favorable in terms of obtaining desirable drug-like properties. The cross-inhibition observed with PARP-1 is most likely attributed to the similarities of substrates in the active sites of both enzymes. Furthermore, 5a demonstrated cell permeability for both PARP and PARG inhibition in intact cells. These studies point to future challenges for obtaining inhibitors highly selective for PARG. At the same time, inhibitors that disrupt PAR metabolism via effects on both cellular PARPs and PARG may represent a new approach for the therapeutic targeting of PAR metabolism.

\section{Experimental section}

\section{Reagents}

High specific activity (22,833 U/mg) PARP-1 was from Trevigen Inc. (Gaithersburg, MD). $\left.{ }^{32} \mathrm{P}\right]-\mathrm{NAD}^{+}$was from Perkin Elmer (Waltham, MA). All rPARG-CF was prepared as a 3.3 $\mathrm{mg} / \mathrm{mL}$ stock as previously described. ${ }^{48}$

\section{PARG assay}

This assay utilizes the conditions previously reported. ${ }^{49}$ Reaction mixtures were prepared in a 1.5 -mL microfuge tube by adding $10 \mu \mathrm{L}$ of $3 \times$ glyco assay buffer $(150 \mathrm{mM}$ potassium phosphate buffer, $\mathrm{pH} 7.5,150 \mathrm{mM} \mathrm{KCl}, 0.3 \mathrm{mg} / \mathrm{mL}$ BSA and $30 \mathrm{mM}$ 2-mercaptoethanol), 5 $\mu \mathrm{L}$ of $60 \mu \mathrm{M}$ [ $\alpha-32 \mathrm{P}] \mathrm{ADP}$-ribose polymers (approx. $5000 \mathrm{cpm} / \mu \mathrm{L}$ ), $7 \mu \mathrm{L}$ of deionized water, and $3 \mu \mathrm{L}$ of test inhibitor in 50\% DMSO. The reaction was initiated by the addition of $5 \mu \mathrm{L}$ of PARG $(0.3 \mu \mathrm{g} / \mathrm{mL})$ and the reaction mixture was incubated at $37^{\circ} \mathrm{C}$ for $5 \mathrm{~min}$. The reaction was then stopped by the addition of $3 \mu \mathrm{L}$ of $1 \%$ SDS. Next, $3 \mu \mathrm{L}$ of the reaction mixture was loaded on to a $2 \times 10 \mathrm{~cm}$ poly(ethyleneimine)-cellulose F TLC plate, prespotted with $1 \mu \mathrm{L}$ of $10 \mathrm{mM}$ ADP-ribose. The spot was dried and the plate was placed into a TLC tank with $100 \mathrm{~mL}$ of methanol and developed until the solvent front reached the top of the plate. Next, the plate was transferred into a second tank containing $100 \mathrm{~mL}$ of a solution comprising $0.9 \mathrm{M}$ acetic acid and $0.3 \mathrm{M} \mathrm{LiCl}$. After developing the plate as before, it was air-dried and the ADP-ribose spot was visualized by using a hand-held short-wave UV lamp. The origin and ADP-ribose spot were excised, placed into 20 -mL scintillation vials with 10 $\mathrm{mL}$ of EcoLume added, and the radioactivity was counted in a Beckman liquid scintillation counter.

\section{PARP-1 assay}

PARP-1 was diluted by PARP dilution buffer containing $50 \mathrm{mM}$ Tris-HCl (pH 8.0), $1 \mathrm{mM}$ DTT, $4 \mathrm{mM} \mathrm{MgCl} 2,1 \mathrm{mM}$ PMSF, $2 \mu \mathrm{g} / \mathrm{mL}$ aprotinin, and $0.3 \mathrm{mg} / \mathrm{mL}$ BSA. The reaction was initiated by addition of PARP-1 to the PARP reaction mixture containing $100 \mathrm{mM}$ Tris$\mathrm{HCl}(\mathrm{pH} \mathrm{8.0)}, 10 \mathrm{mM} \mathrm{MgCl} 2,2 \mathrm{mM}$ DTT, $5 \mu \mathrm{g}$ histone $\mathrm{H} 1,5 \mu \mathrm{g}$ activated DNA, $0.1 \mathrm{mM}$ $\mathrm{NAD}^{+}$, and 50,000 cpm [ $\left.{ }^{32} \mathrm{P}\right]-\mathrm{NAD}^{+}$. The incubation time was 15 minutes. The reaction was terminated by addition of $12.5 \mathrm{Kl}$ ice-cold $100 \% \mathrm{TCA}$, and $5 \mathrm{Kl}$ of BSA $(10 \mathrm{mg} / \mathrm{mL})$ was added and the mixture was cooled at $-20^{\circ} \mathrm{C}$ for 10 minutes, before a 15 minute centrifugation at $4^{\circ} \mathrm{C}$ and $14,000 \mathrm{rpm}$. The supernatant was collected and the pellet was washed with $100 \mathrm{Kl}$ of $20 \% \mathrm{TCA}$ and subjected to a second centrifugation for 15 minutes at $4^{\circ} \mathrm{C}$ at $14,000 \mathrm{rpm}$. The supernatant was collected as the wash and the pellet was suspended in $100 \mathrm{Kl} 88 \%$ formic acid and collected as the pellet.

\section{NAD assay}

The NAD recycling assay as described by Jacobson and Jacobson was followed with minor adjustments. ${ }^{50}$ Briefly, $90 \%$ confluent SCC- 25 cells in $35 \mathrm{~mm}$ dishes were pretreated for 5 minutes with test compound before being treated with $5 \mu \mathrm{g} / \mathrm{mL}$ MNNG. After 30 minutes the media was removed and washed with $1 \mathrm{~mL}$ PBS twice before being treated with $0.2 \mathrm{~mL}$ 
of ice-cold $0.5 \mathrm{M} \mathrm{HClO}_{4}$. Cells were scraped from the dish and washed with an additional $0.2 \mathrm{~mL}$ of $\mathrm{HClO}_{4}$. Cell extracts were then centrifuged at $14,000 \mathrm{rpm}$ for 10 minutes at $4^{\circ} \mathrm{C}$. Supernatants were neutralized with $135 \mu \mathrm{L} 2 \mathrm{M} \mathrm{KOH} / 0.66 \mathrm{M} \mathrm{KH}_{2} \mathrm{PO}_{4}$ (to adjust $\mathrm{pH}$ to 7.0 7.5) and used for the measurement of NAD. The $\mathrm{KClO}_{4}$ precipitate was removed and $20 \mu \mathrm{L}$ of the supernatant was incubated for 30 minutes at $37^{\circ} \mathrm{C}$ with $2 \mathrm{mM}$ phenazine ethosulfate, $0.5 \mathrm{mM}$ 3-(4,5-dimethylthiazol-2-yl)-2,5-diphenyltetrazoliumbromide, $50 \mathrm{mM}$ EDTA, 600 $\mathrm{mM}$ ethanol, and $120 \mathrm{mM}$ Bicine, $\mathrm{pH} 7.8$ and alcohol dehydrogenase $(50 \mu \mathrm{g} / \mathrm{mL}$, Sigma) in a 96-well plate. Absorbance was determined at $570 \mathrm{~nm}$ using a VERSAmax plate reader. Detected NAD content was normalized to cell protein content.

\section{PAR assay}

High throughput chemiluminescent ELISA (HT PARP in vivo pharmacodynamic assay II developed by Trevigen) was used to quantify ADP-ribose polymers in adherent cultured cells. The procedure followed was according to the supplied protocol, with minor adjustments. Briefly, $90 \%$ confluent SCC- 25 cells in $35 \mathrm{~mm}$ dishes were treated with $5 \mu \mathrm{g} /$ mL MNNG. Cells were harvested by addition of lysis buffer containing 1\% SDS. Detected PAR levels were normalized to cell count.

\section{SAR studies}

Inhibition assays were performed in duplicate with selected inhibitors in 5\% DMSO. The catalytic activity of PARG and PARP-1 were measured in the presence of varying concentrations of inhibitors. Data were fit to the equation describing a sigmoidal dose response relation between \% activity (100 to 0 ) and $\log$ [inhibitor] using GraphPad prism version 4 for Windows, GraphPad Software, San Diego, CA, www.graphpad.com. The procedure resulted in calculated values for $\log \mathrm{IC}_{50}$ and standard error which are reported.

\section{Chemistry}

Starting materials were purchased from Aldrich and Alfa-Aesar and used without further purification unless otherwise specified. Flash column chromatography was performed on silica gel (200-400 mesh, $60 \AA$ A) eluting with $\mathrm{CH}_{2} \mathrm{Cl}_{2}$. Proton (1H NMR) nuclear magnetic resonance spectra were recorded on a Bruker Avance spectrometer at $300 \mathrm{MHz}$. Chemical shifts $(\delta)$ are in parts per million (ppm) relative to $\mathrm{Si}\left(\mathrm{CH}_{3}\right)_{4}$, and coupling constants $(J)$ are in hertz. The NMR solvent used was DMSO- $d_{6}$. For routine aqueous workup, the reaction mixture was extracted with $\mathrm{CH}_{2} \mathrm{Cl}_{2}$ or EtOAc. The organic layer was washed twice with $\mathrm{Na}_{2} \mathrm{HCO}_{3}$, once with brine, dried over anhydrous $\mathrm{MgSO}_{4}$, and concentrated with a Büchi rotary evaporator. All compounds tested in assays were $>95 \%$ purity as determined by RPHPLC, using 0.5\% TFA (aq):MeOH (2:8) elution phase.

\section{General procedure for the synthesis of compounds $2 a-2 g$}

To selected nitrobenzenes ( $4 \mathrm{mmol})$ in toluene were added substituted phenols $(6 \mathrm{mmol}, 1.5$ equiv) and $\mathrm{Cs}_{2} \mathrm{CO}_{3}$ (12 mmol, 3 equiv) and left stirring under nitrogen. The reaction was kept at $100^{\circ} \mathrm{C}$ and left until completion (24-36 hours). The reaction progress was monitored by TLC (15\% EtOAc/hexane), and once all nitro aryl halide was reacted, the solvent was removed in vacuo and redissolved in EtOAc. The mixture was then filtered, and routine aqueous workup was performed on the filtrate. The organic phase was concentrated and purified by column chromatography (5\% EtOAc/hexane) to obtain compounds $\mathbf{2} \mathbf{a}-\mathbf{2} \mathbf{g}$ as red and yellow oils.

2-(2-chloro-4-nitrophenoxy)naphthalene (2a)-(57\%); $\mathrm{R}_{\mathrm{f}}=0.60(15 \%$ EtOAc/ hexane); ${ }^{1} \mathrm{H}$ NMR $\left(300 \mathrm{MHz}, \mathrm{DMSO}-d_{6}\right) \delta 8.48(\mathrm{~d}, J=2.7 \mathrm{~Hz}, 1 \mathrm{H}), 8.16(\mathrm{dd}, J=9.1,2.8$ $\mathrm{Hz}, 1 \mathrm{H}), 8.07(\mathrm{~d}, J=8.9 \mathrm{~Hz}, 1 \mathrm{H}), 7.99(\mathrm{~d}, J=7.1 \mathrm{~Hz}, 1 \mathrm{H}), 7.90(\mathrm{~d}, J=7.0 \mathrm{~Hz}, 1 \mathrm{H}), 7.67$ (d, 
$J=2.0 \mathrm{~Hz}, 1 \mathrm{H}), 7.54(\mathrm{tt}, J=6.9,5.3 \mathrm{~Hz}, 2 \mathrm{H}), 7.40(\mathrm{dd}, J=8.9,2.4 \mathrm{~Hz}, 1 \mathrm{H}), 7.12(\mathrm{~d}, J=9.1$ $\mathrm{Hz}, 1 \mathrm{H})$.

2-(4-nitrophenoxy)naphthalene (2b)-(52\%); $\mathrm{R}_{\mathrm{f}}=0.67$ (15\% EtOAc/hexane); ${ }^{1} \mathrm{H}$ NMR $\left(300 \mathrm{MHz}\right.$, DMSO-d $\left.d_{6}\right) \delta 8.27(\mathrm{~d}, J=9.2 \mathrm{~Hz}, 2 \mathrm{H}), 8.07(\mathrm{~d}, J=8.9 \mathrm{~Hz}, 1 \mathrm{H}), 8.00(\mathrm{~d}, J$ $=7.0 \mathrm{~Hz}, 1 \mathrm{H}), 7.92(\mathrm{~d}, J=7.4 \mathrm{~Hz}, 1 \mathrm{H}), 7.71(\mathrm{~d}, J=2.2 \mathrm{~Hz}, 1 \mathrm{H}), 7.55(\mathrm{~m}, 2 \mathrm{H}), 7.39(\mathrm{dd}, J=$ $8.9,2.4 \mathrm{~Hz}, 1 \mathrm{H}), 7.21(\mathrm{~d}, J=9.2 \mathrm{~Hz}, 2 \mathrm{H})$.

2-(2-fluoro-4-nitrophenoxy)naphthalene (2c)-(58\%); $\mathrm{R}_{\mathrm{f}}=0.45(15 \% \mathrm{EtOAc} /$ hexane); ${ }^{1} \mathrm{H}$ NMR $\left(300 \mathrm{MHz}, \mathrm{DMSO}-d_{6}\right) \delta 8.37(\mathrm{dd}, J=10.8,2.7 \mathrm{~Hz}, 1 \mathrm{H}), 8.10(\mathrm{~d}, J=2.7$ $\mathrm{Hz}, 1 \mathrm{H}), 8.06(\mathrm{~d}, J=8.8 \mathrm{~Hz}, 1 \mathrm{H}), 7.98(\mathrm{~d}, J=7.3 \mathrm{~Hz}, 1 \mathrm{H}), 7.89(\mathrm{~d}, J=7.2 \mathrm{~Hz}, 1 \mathrm{H}), 7.66(\mathrm{~d}$, $J=2.0 \mathrm{~Hz}, 1 \mathrm{H}), 7.53(\mathrm{~m}, 2 \mathrm{H}), 7.42(\mathrm{dd}, J=8.9,2.4 \mathrm{~Hz}, 1 \mathrm{H}), 7.25(\mathrm{~d}, J=8.4 \mathrm{~Hz}, 1 \mathrm{H})$.

2-(4-nitro-2-(trifluoromethyl)phenoxy)naphthalene (2d)-(66\%); $\mathrm{R}_{\mathrm{f}}=0.70(15 \%$ EtOAc/hexane); ${ }^{1} \mathrm{H}$ NMR (300 MHz, DMSO- $\left.d_{6}\right) \delta 8.55(\mathrm{~d}, J=2.6 \mathrm{~Hz}, 1 \mathrm{H}), 8.45$ (dd, $J=$ $9.2,2.7 \mathrm{~Hz}, 1 \mathrm{H}), 8.11(\mathrm{~d}, J=8.9 \mathrm{~Hz}, 1 \mathrm{H}), 8.02(\mathrm{~d}, J=6.6 \mathrm{~Hz}, 1 \mathrm{H}), 7.95(\mathrm{~d}, J=7.0 \mathrm{~Hz}, 1 \mathrm{H})$, $7.79(\mathrm{~d}, J=2.2 \mathrm{~Hz}, 1 \mathrm{H}), 7.58(\mathrm{~m}, 2 \mathrm{H}), 7.41(\mathrm{dd}, J=8.9,2.0 \mathrm{~Hz}, 1 \mathrm{H}), 7.18(\mathrm{~d}, J=9.2 \mathrm{~Hz}$, $1 \mathrm{H})$.

2-(2-methyl-4-nitrophenoxy)naphthalene (2e)-(43\%); $\mathrm{R}_{\mathrm{f}}=0.54(15 \% \mathrm{EtOAc} /$ hexane); ${ }^{1} \mathrm{H}$ NMR (300 MHz, DMSO- $\left.d_{6}\right) \delta 8.27(\mathrm{~d}, J=2.6 \mathrm{~Hz}, 1 \mathrm{H}), 8.05(\mathrm{dd}, J=8.8,4.1$ $\mathrm{Hz}, 2 \mathrm{H}), 7.97(\mathrm{~d}, J=7.2 \mathrm{~Hz}, 1 \mathrm{H}), 7.87(\mathrm{~d}, J=6.9 \mathrm{~Hz}, 1 \mathrm{H}), 7.57(\mathrm{~d}, J=1.9 \mathrm{~Hz}, 1 \mathrm{H}), 7.52$ $(\mathrm{m}, 2 \mathrm{H}), 7.35(\mathrm{dd}, J=8.9,2.4 \mathrm{~Hz}, 1 \mathrm{H}), 6.93(\mathrm{~d}, J=9.0 \mathrm{~Hz}, 1 \mathrm{H}), 2.41(\mathrm{~s}, 3 \mathrm{H}) .=0.65(15 \%$ EtOAc/hexane); ${ }^{1} \mathrm{H}$ NMR (300

2-chloro-4-nitro-1-(p-tolyloxy)benzene (2f)-(58\%); $\mathrm{R}_{\mathrm{f}} \mathrm{MHz}$, DMSO- $\left.d_{6}\right) \delta 8.42$ (d, $J$ $=2.7 \mathrm{~Hz}, 1 \mathrm{H}), 8.14(\mathrm{dd}, J=9.2,2.8 \mathrm{~Hz}, 1 \mathrm{H}), 7.30(\mathrm{~d}, J=8.4 \mathrm{~Hz}, 2 \mathrm{H}), 7.08(\mathrm{~d}, J=8.4 \mathrm{~Hz}$, $2 \mathrm{H}), 6.94(\mathrm{~d}, J=9.2 \mathrm{~Hz}, 1 \mathrm{H}), 2.33$ (s, 3H). 2-chloro-4-nitro-1-phenoxybenzene (2g) $(68 \%)$; $\mathrm{R}_{\mathrm{f}}=0.56\left(15 \%\right.$ EtOAc/hexane); ${ }^{1} \mathrm{H}$ NMR $\left(300 \mathrm{MHz}\right.$, DMSO- $\left.d_{6}\right) \delta 8.46(\mathrm{~d}, J=2.7 \mathrm{~Hz}, 1 \mathrm{H})$, $8.18(\mathrm{dd}, J=9.1,2.7 \mathrm{~Hz}, 1 \mathrm{H}), 7.51(\mathrm{t}, J=7.8 \mathrm{~Hz}, 1 \mathrm{H}), 7.32(\mathrm{t}, J=7.6 \mathrm{~Hz}, 1 \mathrm{H}), 7.19(\mathrm{~d}, J=$ $7.8 \mathrm{~Hz}, 1 \mathrm{H}), 7.15(\mathrm{t}, J=7.8 \mathrm{~Hz}, 1 \mathrm{H}), 7.02(\mathrm{~d}, J=9.1 \mathrm{~Hz}, 1 \mathrm{H}), 6.74(\mathrm{~d}, J=7.9 \mathrm{~Hz}, 1 \mathrm{H})$.

\section{General procedure for the synthesis of compounds $3 a-3 g$}

To $2 \mathbf{a}-2 \mathrm{~g}$ (3.0 $\mathrm{mmol})$ dissolved in absolute ethanol and purged with nitrogen was added $\mathrm{SnCl}_{2}\left(15.0 \mathrm{mmol}, 5\right.$ equiv) and left stirring at $70^{\circ} \mathrm{C}$. Completion was monitored by TLC $\left(\mathrm{CH}_{2} \mathrm{Cl}_{2}\right)$, and extra $\mathrm{SnCl}_{2}$ was added as needed. Once completed (usually $3 \mathrm{~h}$ ), the solvent was removed in vacuo, and redissolved in EtOAc. The mixture was poured onto ice, and the $\mathrm{pH}$ adjusted to 9.0 with $6 \mathrm{M} \mathrm{NaOH}$. This mixture was then filtered, and routine aqueous workup was performed. The organic phase was concentrated and purified by column chromatography $\left(\mathrm{CH}_{2} \mathrm{Cl}_{2}\right)$ to obtain $\mathbf{3 a - 3 g}$ as yellow-orange oils.

3-chloro-4-(naphthalen-2-yloxy)aniline (3a)- $(55 \%) ; \mathrm{R}_{\mathrm{f}}=0.35\left(\mathrm{CH}_{2} \mathrm{Cl}_{2}\right) ;{ }^{1} \mathrm{H} \mathrm{NMR}$ $\left(300 \mathrm{MHz}, \mathrm{DMSO}-d_{6}\right) \delta 7.91(\mathrm{~d}, J=9.0 \mathrm{~Hz}, 1 \mathrm{H}), 7.87(\mathrm{~d}, J=8.1 \mathrm{~Hz}, 1 \mathrm{H}), 7.75(\mathrm{~d}, J=8.1$ $\mathrm{Hz}, 1 \mathrm{H}), 7.41(\mathrm{dt}, J=14.7,6.8 \mathrm{~Hz}, 2 \mathrm{H}), 7.24(\mathrm{dd}, J=9.0,1.8 \mathrm{~Hz}, 1 \mathrm{H}), 7.01(\mathrm{~d}, J=3.3 \mathrm{~Hz}$, $1 \mathrm{H}), 6.99(\mathrm{~d}, J=5.0 \mathrm{~Hz}, 1 \mathrm{H}), 6.76(\mathrm{~d}, J=1.8 \mathrm{~Hz}, 1 \mathrm{H}), 6.60(\mathrm{dd}, J=8.6,1.8 \mathrm{~Hz}, 1 \mathrm{H}), 5.38$ (s, 2H).

4-(naphthalen-2-yloxy)aniline (3b)-(45\%); $\mathrm{R}_{\mathrm{f}}=0.40\left(\mathrm{CH}_{2} \mathrm{Cl}_{2}\right) ;{ }^{1} \mathrm{H} \mathrm{NMR}(300 \mathrm{MHz}$, DMSO- $\left.d_{6}\right) \delta 7.87(\mathrm{~d}, J=9.2 \mathrm{~Hz}, 1 \mathrm{H}), 7.84(\mathrm{~d}, J=8.8 \mathrm{~Hz}, 1 \mathrm{H}), 7.71(\mathrm{~d}, J=7.8 \mathrm{~Hz}, 1 \mathrm{H})$, $7.39(\mathrm{dt}, J=20.1,6.7 \mathrm{~Hz}, 2 \mathrm{H}), 7.24(\mathrm{dd}, J=8.9,2.5 \mathrm{~Hz}, 1 \mathrm{H}), 7.13(\mathrm{~d}, J=2.4 \mathrm{~Hz}, 1 \mathrm{H}), 6.86$ $(\mathrm{d}, J=8.7 \mathrm{~Hz}, 2 \mathrm{H}), 6.66(\mathrm{~d}, J=8.7 \mathrm{~Hz}, 2 \mathrm{H}), 5.04(\mathrm{~s}, 2 \mathrm{H})$. 
3-fluoro-4-(naphthalen-2-yloxy)aniline (3c)-(61\%); $\mathrm{R}_{\mathrm{f}}=0.35\left(\mathrm{CH}_{2} \mathrm{Cl}_{2}\right) ;{ }^{1} \mathrm{H}$ NMR $\left(300 \mathrm{MHz}, \mathrm{DMSO}-d_{6}\right) \delta 7.90(\mathrm{~d}, J=9.1 \mathrm{~Hz}, 1 \mathrm{H}), 7.87(\mathrm{~d}, J=10.4 \mathrm{~Hz}, 1 \mathrm{H}), 7.76(\mathrm{~d}, J=8.1$ $\mathrm{Hz}, 1 \mathrm{H}), 7.41(\mathrm{dt}, J=20.4,6.8 \mathrm{~Hz}, 2 \mathrm{H}), 7.26(\mathrm{dd}, J=8.9,2.5 \mathrm{~Hz}, 1 \mathrm{H}), 7.07(\mathrm{~d}, J=2.2 \mathrm{~Hz}$, $1 \mathrm{H}), 6.98(\mathrm{~d}, J=9.1 \mathrm{~Hz}, 1 \mathrm{H}), 6.53(\mathrm{dd}, J=13.3,2.5 \mathrm{~Hz}, 1 \mathrm{H}), 6.43(\mathrm{dd}, J=8.7,1.7 \mathrm{~Hz}, 1 \mathrm{H})$, $5.39(\mathrm{~s}, 2 \mathrm{H})$.

4-(naphthalen-2-yloxy)-3-(trifluoromethyl)aniline (3d)—(55\%); $\mathrm{R}_{\mathrm{f}}=0.44$ $\left(\mathrm{CH}_{2} \mathrm{Cl}_{2}\right) ;{ }^{1} \mathrm{H}$ NMR $\left(300 \mathrm{MHz}\right.$, DMSO- $\left.d_{6}\right) \delta 7.90(\mathrm{~d}, J=9.3 \mathrm{~Hz}, 1 \mathrm{H}), 7.87(\mathrm{~d}, J=10.0 \mathrm{~Hz}$, $1 \mathrm{H}), 7.77(\mathrm{~d}, J=6.7 \mathrm{~Hz}, 1 \mathrm{H}), 7.42(\mathrm{~m}, 2 \mathrm{H}), 7.22(\mathrm{dd}, J=9.1,2.3 \mathrm{~Hz}, 1 \mathrm{H}), 7.14(\mathrm{~d}, J=2.0$ $\mathrm{Hz}, 1 \mathrm{H}), 6.97(\mathrm{~d}, J=6.0 \mathrm{~Hz}, 1 \mathrm{H}), 6.95(\mathrm{~d}, J=2.2 \mathrm{~Hz}, 1 \mathrm{H}), 6.85(\mathrm{dd}, J=8.8,2.2 \mathrm{~Hz}, 1 \mathrm{H})$, $5.50(\mathrm{~s}, 2 \mathrm{H})$.

2-(2-methyl-4-nitrophenoxy)naphthalene (3e)-(59\%); $\mathrm{R}_{\mathrm{f}}=0.29\left(\mathrm{CH}_{2} \mathrm{Cl}_{2}\right) ;{ }^{1} \mathrm{H} \mathrm{NMR}$ $\left(300 \mathrm{MHz}\right.$, DMSO- $\left.d_{6}\right) \delta 7.91(\mathrm{~d}, J=9.0 \mathrm{~Hz}, 1 \mathrm{H}), 7.86(\mathrm{~d}, J=8.0 \mathrm{~Hz}, 1 \mathrm{H}), 7.72(\mathrm{~d}, J=8.3$ $\mathrm{Hz}, 1 \mathrm{H}), 7.40(\mathrm{dt}, J=14.7,6.9 \mathrm{~Hz}, 2 \mathrm{H}), 7.24(\mathrm{dd}, J=8.8,2.2 \mathrm{~Hz}, 1 \mathrm{H}), 7.00(\mathrm{~d}, J=1.6 \mathrm{~Hz}$, $1 \mathrm{H}), 6.84(\mathrm{~d}, J=8.4 \mathrm{~Hz}, 1 \mathrm{H}), 6.71(\mathrm{~d}, J=2.0 \mathrm{~Hz}, 1 \mathrm{H}), 6.64(\mathrm{dd}, J=8.2,1.9 \mathrm{~Hz}, 1 \mathrm{H}), 6.54$ (br s, 2H).

3-chloro-4-(p-tolyloxy)aniline (3f)—(47\%); $\mathrm{R}_{\mathrm{f}}=0.40\left(\mathrm{CH}_{2} \mathrm{Cl}_{2}\right) ;{ }^{1} \mathrm{H} \mathrm{NMR}(300 \mathrm{MHz}$, DMSO- $\left.d_{6}\right) \delta 7.09(\mathrm{~d}, J=8.4 \mathrm{~Hz}, 2 \mathrm{H}), 6.86(\mathrm{~d}, J=8.3 \mathrm{~Hz}, 1 \mathrm{H}), 6.70(\mathrm{~d}, J=1.7 \mathrm{~Hz}, 1 \mathrm{H})$, $6.69(\mathrm{~d}, J=8.1 \mathrm{~Hz}, 2 \mathrm{H}), 6.53(\mathrm{dd}, J=8.7,1.7 \mathrm{~Hz}, 1 \mathrm{H}), 5.29(\mathrm{~s}, 2 \mathrm{H}), 2.23(\mathrm{~s}, 3 \mathrm{H})$.

3-chloro-4-phenoxyaniline (3g)—(52\%); $\mathrm{R}_{\mathrm{f}}=0.27\left(\mathrm{CH}_{2} \mathrm{Cl}_{2}\right) ;{ }^{1} \mathrm{H} \mathrm{NMR}(300 \mathrm{MHz}$, DMSO- $\left.d_{6}\right) \delta 7.30(\mathrm{t}, J=7.2 \mathrm{~Hz}, 2 \mathrm{H}), 7.00(\mathrm{t}, J=7.3 \mathrm{~Hz}, 1 \mathrm{H}), 6.90(\mathrm{~d}, J=8.7 \mathrm{~Hz}, 1 \mathrm{H}), 6.79$ $(\mathrm{d}, J=7.8 \mathrm{~Hz}, 2 \mathrm{H}), 6.72(\mathrm{~d}, J=2.6 \mathrm{~Hz}, 1 \mathrm{H}), 6.55(\mathrm{dd}, J=8.7,2.6 \mathrm{~Hz}, 1 \mathrm{H}), 5.32(\mathrm{~s}, 2 \mathrm{H})$.

3,5-dichloro-2-methoxybenzoic acid (4)-To $1.2 \mathrm{~g}$ (5.8 mmol) 3,5-dichloro salicylic acid and $3 \mathrm{~g}$ ( $21.7 \mathrm{mmol}, 3.7$ equiv) $\mathrm{K}_{2} \mathrm{CO}_{3}$ in $20 \mathrm{~mL}$ acetone was added $1 \mathrm{~mL}$ (17.7 mmol, 3 equiv) of iodomethane and refluxed overnight. After $24 \mathrm{hrs}$ the solution was cooled to RT. $10 \mathrm{~mL}$ of methanol was added followed by $5 \mathrm{~mL}$ of $6 \mathrm{M} \mathrm{NaOH}$ and further refluxed for 3 hrs. The solution was acidified by the addition of $6 \mathrm{M} \mathrm{HCl} \mathrm{until} \mathrm{pH} 1$ was reached. The precipitate was filtered and collected to obtain 4 as a pure white solid $(80 \%) . \mathrm{R}_{\mathrm{f}}=0.72(10 \%$ $\left.\mathrm{MeOH} / \mathrm{CHCl}_{3}\right) .{ }^{1} \mathrm{H}$ NMR $\left(300 \mathrm{MHz}, \mathrm{DMSO}-d_{6}\right) \delta 13.58(\mathrm{~s}, 1 \mathrm{H}), 7.88(\mathrm{~d}, J=2.6 \mathrm{~Hz}, 1 \mathrm{H})$, $7.67(\mathrm{~d}, J=2.5 \mathrm{~Hz}, 1 \mathrm{H}), 3.82(\mathrm{~s}, 3 \mathrm{H})$.

\section{General procedure for the synthesis of compounds $5 a-5 f$}

Corresponding benzoic acids were heated at $110^{\circ} \mathrm{C}$ in thionyl chloride for $1-2 \mathrm{~h}$. After completion, excess thionyl chloride was removed in vacuo. The product mixture was dissolved in $\mathrm{CH}_{2} \mathrm{Cl}_{2}$ and filtered. Filtrates were concentrated and used without further purification.

\section{General procedure for the synthesis of compounds $6 \mathrm{a}-6 \mathrm{~m}$}

To a stirred solution of amine $\mathbf{3 a - 3} \mathbf{g}(0.2 \mathrm{mmol})$ in $5 \mathrm{~mL}$ of $\mathrm{CH}_{2} \mathrm{Cl}_{2}$ was added benzoic acid chlorides $\mathbf{5 a - 5 f}$ or phthalamic anhydride $(0.2 \mathrm{mmol}, 1$ equiv) and the reaction mixture was stirred at RT for $0.5 \mathrm{~h}$. The reaction was monitored by TLC $\left(\mathrm{CH}_{2} \mathrm{Cl}_{2}\right)$ and once completed the mixture was concentrated and purified by column chromatography $\left(\mathrm{CH}_{2} \mathrm{Cl}_{2}\right)$ to obtain 6a-6m as off-white solids.

\section{3,5-dichloro-N-(3-chloro-4-(naphthalen-2-yloxy)phenyl)-2-hydroxybenzamide} (6a)- $(65 \%) ; \mathrm{R}_{\mathrm{f}}=0.78\left(\mathrm{CH}_{2} \mathrm{Cl}_{2}\right) ;{ }^{1} \mathrm{H}$ NMR $\left(300 \mathrm{MHz}, \mathrm{DMSO}-d_{6}\right) \delta 12.49(\mathrm{br} \mathrm{s}, 1 \mathrm{H})$, $10.77(\mathrm{~s}, 1 \mathrm{H}), 8.09(\mathrm{~d}, J=2.3 \mathrm{~Hz}, 1 \mathrm{H}), 8.07(\mathrm{~d}, J=2.3 \mathrm{~Hz}, 1 \mathrm{H}), 7.98(\mathrm{~d}, J=9.0 \mathrm{~Hz}, 1 \mathrm{H})$, $7.91(\mathrm{~d}, J=7.4 \mathrm{~Hz}, 1 \mathrm{H}), 7.81(\mathrm{~d}, J=2.5 \mathrm{~Hz}, 1 \mathrm{H}), 7.81(\mathrm{~d}, J=5.5,1 \mathrm{H}), 7.70(\mathrm{dd}, J=8.8,2.3$ 
$\mathrm{Hz}, 1 \mathrm{H}), 7.46(\mathrm{~m}, 2 \mathrm{H}), 7.32(\mathrm{dd}, J=9.0,2.4 \mathrm{~Hz}, 1 \mathrm{H}), 7.28(\mathrm{~d}, J=9.3 \mathrm{~Hz}, 1 \mathrm{H}), 7.26(\mathrm{~d}, J=$ 2.4, $1 \mathrm{H})$; MS (ESI) $m / z: 457.9[\mathrm{M}+\mathrm{H}]^{+}$.

3,5-dichloro-N-(3-chloro-4-(naphthalen-2-yloxy)phenyl)benzamide (6b)-(57\%); $\mathrm{R}_{\mathrm{f}}=0.78\left(\mathrm{CH}_{2} \mathrm{Cl}_{2}\right) ;{ }^{1} \mathrm{H}$ NMR $\left(300 \mathrm{MHz}, \mathrm{DMSO}-d_{6}\right) \delta 10.63(\mathrm{~s}, 1 \mathrm{H}), 8.14(\mathrm{t}, J=2.1 \mathrm{~Hz}$, $1 \mathrm{H}), 8.01(\mathrm{~d}, J=1.9 \mathrm{~Hz}, 1 \mathrm{H}), 8.00(\mathrm{~d}, J=1.9 \mathrm{~Hz}, 1 \mathrm{H}), 8.00(\mathrm{~d}, J=1.9 \mathrm{~Hz}, 1 \mathrm{H}), 7.95(\mathrm{~d}, J=$ $11.0 \mathrm{~Hz}, 1 \mathrm{H}), 7.90(\mathrm{~d}, J=1.8 \mathrm{~Hz}, 1 \mathrm{H}), 7.82(\mathrm{~d}, J=8.0 \mathrm{~Hz}, 1 \mathrm{H}), 7.76(\mathrm{dd}, J=8.9,2.3 \mathrm{~Hz}$, $1 \mathrm{H}), 7.46(\mathrm{td}, J=14.7,7.3 \mathrm{~Hz}, 2 \mathrm{H}), 7.32(\mathrm{~d}, J=9.1 \mathrm{~Hz}, 1 \mathrm{H}), 7.29(\mathrm{dd}, J=8.9,2.0 \mathrm{~Hz}, 1 \mathrm{H})$, $7.23(\mathrm{~s}, 1 \mathrm{H}) ; \mathrm{MS}(\mathrm{ESI}) \mathrm{m} / z: 441.9[\mathrm{M}+\mathrm{H}]^{+}$.

N-(3-chloro-4-(naphthalen-2-yloxy)phenyl)-2-hydroxybenzamide (6c)-(43\%); $\mathrm{R}_{\mathrm{f}}$ $=0.69\left(\mathrm{CH}_{2} \mathrm{Cl}_{2}\right) ;{ }^{1} \mathrm{H}$ NMR $\left(300 \mathrm{MHz}\right.$, DMSO- $\left.d_{6}\right) \delta 11.58(\mathrm{~s}, 1 \mathrm{H}), 10.53(\mathrm{~s}, 1 \mathrm{H}), 8.13(\mathrm{~s}$, $1 \mathrm{H}), 7.98(\mathrm{~d}, J=8.8 \mathrm{~Hz}, 1 \mathrm{H}), 7.92(\mathrm{dd}, J=7.9,1.5 \mathrm{~Hz}, 2 \mathrm{H}), 7.82(\mathrm{~d}, J=7.9 \mathrm{~Hz}, 1 \mathrm{H}), 7.71$ $(\mathrm{d}, J=8.9 \mathrm{~Hz}, 1 \mathrm{H}), 7.46(\mathrm{~m}, 3 \mathrm{H}), 7.33(\mathrm{~d}, J=8.9 \mathrm{~Hz}, 1 \mathrm{H}), 7.28(\mathrm{dd}, J=8.9,1.7 \mathrm{~Hz}, 1 \mathrm{H})$, $7.22(\mathrm{~s}, 1 \mathrm{H}), 7.01(\mathrm{~d}, J=9.6 \mathrm{~Hz}, 1 \mathrm{H}), 6.98(\mathrm{~d}, J=8.7 \mathrm{~Hz}, 1 \mathrm{H}) ; \mathrm{MS}(\mathrm{ESI}) \mathrm{m} / z: 390.0[\mathrm{M}+$ $\mathrm{H}]^{+}$.

5-chloro-N-(3-chloro-4-(naphthalen-2-yloxy)phenyl)-2-hydroxybenzamide (6d) - $(67 \%) ; \mathrm{R}_{\mathrm{f}}=0.72\left(\mathrm{CH}_{2} \mathrm{Cl}_{2}\right) ;{ }^{1} \mathrm{H}$ NMR $\left(300 \mathrm{MHz}, \mathrm{DMSO}-d_{6}\right) \delta 11.73(\mathrm{br} \mathrm{s}, 1 \mathrm{H}), 10.56(\mathrm{~s}$, $1 \mathrm{H}), 8.12(\mathrm{~d}, J=2.3 \mathrm{~Hz}, 1 \mathrm{H}), 7.95(\mathrm{~d}, J=9.1 \mathrm{~Hz}, 1 \mathrm{H}), 7.93(\mathrm{~d}, J=2.6 \mathrm{~Hz}, 1 \mathrm{H}), 7.89(\mathrm{~d}, J=$ $7.9 \mathrm{~Hz}, 1 \mathrm{H}), 7.79(\mathrm{~d}, J=8.0 \mathrm{~Hz}, 1 \mathrm{H}), 7.70(\mathrm{dd}, J=8.8,2.3 \mathrm{~Hz}, 1 \mathrm{H}), 7.47(\mathrm{dd}, J=5.0,3.8$ $\mathrm{Hz}, 1 \mathrm{H}), 7.45(\mathrm{~m}, 2 \mathrm{H}), 7.31(\mathrm{dd}, J=8.9,2.4 \mathrm{~Hz}, 1 \mathrm{H}), 7.26(\mathrm{~d}, J=8.9 \mathrm{~Hz}, 1 \mathrm{H}), 7.22(\mathrm{~d}, J=$ $2.1 \mathrm{~Hz}, 1 \mathrm{H}), 7.03(\mathrm{~d}, J=8.8 \mathrm{~Hz}, 1 \mathrm{H})$; MS (ESI) $m / z: 424.0[\mathrm{M}+\mathrm{H}]^{+}$.

3-chloro-N-(3-chloro-4-(naphthalen-2-yloxy)phenyl)-2-hydroxybenzamide (6e) - $(50 \%) ; \mathrm{R}_{\mathrm{f}}=0.72\left(\mathrm{CH}_{2} \mathrm{Cl}_{2}\right) ;{ }^{1} \mathrm{H}$ NMR $\left(300 \mathrm{MHz}, \mathrm{DMSO}-d_{6}\right) \delta 12.45(\mathrm{~s}, 1 \mathrm{H}), 10.76(\mathrm{~s}$, $1 \mathrm{H}), 8.08(\mathrm{~s}, 1 \mathrm{H}), 7.99(\mathrm{~d}, J=8.5 \mathrm{~Hz}, 2 \mathrm{H}), 7.92(\mathrm{~d}, J=7.5 \mathrm{~Hz}, 1 \mathrm{H}), 7.83(\mathrm{~d}, J=7.7 \mathrm{~Hz}$, $1 \mathrm{H}), 7.70(\mathrm{t}, J=9.9 \mathrm{~Hz}, 2 \mathrm{H}), 7.47(\mathrm{~m}, 2 \mathrm{H}), 7.33(\mathrm{~d}, J=10.4 \mathrm{~Hz}, 1 \mathrm{H}), 7.29(\mathrm{~d}, J=11.5 \mathrm{~Hz}$, 1H), $7.26(\mathrm{~d}, J=5.1 \mathrm{~Hz}, 1 \mathrm{H}), 7.03(\mathrm{t}, J=7.3 \mathrm{~Hz}, 1 \mathrm{H})$; MS (ESI) $m / z: 424.0[\mathrm{M}+\mathrm{H}]^{+}$.

3,5-dichloro-N-(3-chloro-4-(naphthalen-2-yloxy)phenyl)-2-methoxybenzamide (6f)—(55\%); $\mathrm{R}_{\mathrm{f}}=0.67\left(\mathrm{CH}_{2} \mathrm{Cl}_{2}\right) ;{ }^{1} \mathrm{H}$ NMR $\left(300 \mathrm{MHz}, \mathrm{DMSO}-d_{6}\right) \delta 10.75(\mathrm{~s}, 1 \mathrm{H}), 8.12(\mathrm{~d}$, $J=2.5 \mathrm{~Hz}, 1 \mathrm{H}), 7.97(\mathrm{~d}, J=9.0 \mathrm{~Hz}, 1 \mathrm{H}), 7.91(\mathrm{~d}, J=7.8 \mathrm{~Hz}, 1 \mathrm{H}), 7.85(\mathrm{~d}, J=2.6 \mathrm{~Hz}, 1 \mathrm{H})$, $7.81(\mathrm{~d}, J=7.9 \mathrm{~Hz}, 1 \mathrm{H}), 7.67(\mathrm{dd}, J=7.0,2.5 \mathrm{~Hz}, 1 \mathrm{H}), 7.65(\mathrm{~d}, J=1.8 \mathrm{~Hz}, 1 \mathrm{H}), 7.45(\mathrm{~m}$, 2H), 7.32 (dd, $J=9.4,2.0 \mathrm{~Hz}, 1 \mathrm{H}), 7.29(\mathrm{~d}, J=7.5 \mathrm{~Hz}, 1 \mathrm{H}), 7.22(\mathrm{~d}, J=2.4 \mathrm{~Hz}, 1 \mathrm{H}), 3.87$ (s, 3H); MS (ESI) $m / z: 470.1[\mathrm{M}-\mathrm{H}]^{-}$.

2-(3-chloro-4-(naphthalen-2-yloxy)phenylcarbamoyl)benzoic acid (6g)-(92\%); $\mathrm{R}_{\mathrm{f}}=0.22\left(10 \% \mathrm{MeOH} / \mathrm{CHCl}_{3}\right) ;{ }^{1} \mathrm{H}$ NMR $\left(300 \mathrm{MHz}, \mathrm{DMSO}-d_{6}\right) \delta 13.12(\mathrm{~s}, 1 \mathrm{H}), 10.64(\mathrm{~s}$, $1 \mathrm{H}), 8.10(\mathrm{~d}, J=2.4 \mathrm{~Hz}, 1 \mathrm{H}), 7.97(\mathrm{~d}, J=8.9 \mathrm{~Hz}, 1 \mathrm{H}), 7.91(\mathrm{~d}, J=7.8 \mathrm{~Hz}, 2 \mathrm{H}), 7.83(\mathrm{~d}, J=$ $7.5 \mathrm{~Hz}, 1 \mathrm{H}), 7.68(\mathrm{~d}, J=7.3 \mathrm{~Hz}, 1 \mathrm{H}), 7.61(\mathrm{~m}, 3 \mathrm{H}), 7.46(\mathrm{~m}, 2 \mathrm{H}), 7.32(\mathrm{dd}, J=9.6,3.2 \mathrm{~Hz}$, 1H), $7.28(\mathrm{~d}, J=8.9 \mathrm{~Hz}, 1 \mathrm{H}), 7.19(\mathrm{~d}, J=2.4 \mathrm{~Hz}, 1 \mathrm{H})$; MS (ESI) m/z: $417.9[\mathrm{M}+\mathrm{H}]^{+}$.

\section{3,5-dichloro-2-hydroxy-N-(4-(naphthalen-2-yloxy)phenyl)benzamide (6h)-} $(47 \%) ; \mathrm{R}_{\mathrm{f}}=0.60\left(\mathrm{CH}_{2} \mathrm{Cl}_{2}\right) ;{ }^{1} \mathrm{H}$ NMR $\left(300 \mathrm{MHz}, \mathrm{DMSO}-d_{6}\right) \delta 12.82(\mathrm{br} \mathrm{s}, 1 \mathrm{H}), 10.74(\mathrm{~s}$, $1 \mathrm{H}), 8.13(\mathrm{~d}, J=2.4 \mathrm{~Hz}, 1 \mathrm{H}), 7.98(\mathrm{~d}, J=8.9 \mathrm{~Hz}, 1 \mathrm{H}), 7.92(\mathrm{~d}, J=7.7 \mathrm{~Hz}, 1 \mathrm{H}), 7.84(\mathrm{~d}, J=$ $5.6 \mathrm{~Hz}, 1 \mathrm{H}), 7.82(\mathrm{~d}, J=2.1 \mathrm{~Hz}, 1 \mathrm{H}), 7.74(\mathrm{~d}, J=8.8 \mathrm{~Hz}, 2 \mathrm{H}), 7.47(\mathrm{~m}, 2 \mathrm{H}), 7.39(\mathrm{~d}, J=2.2$ $\mathrm{Hz}, 1 \mathrm{H}), 7.32$ (dd, $J=8.9,2.3 \mathrm{~Hz}, 1 \mathrm{H}), 7.16(\mathrm{~d}, J=8.8 \mathrm{~Hz}, 2 \mathrm{H})$; MS (ESI) $\mathrm{m} / z: 422.4$ [M $\mathrm{H}]^{-}$.

3,5-dichloro-N-(3-fluoro-4-(naphthalen-2-yloxy)phenyl)-2-hydroxybenzamide (6i)—(57\%); $\mathrm{R}_{\mathrm{f}}=0.72\left(\mathrm{CH}_{2} \mathrm{Cl}_{2}\right) ;{ }^{1} \mathrm{H}$ NMR $\left(300 \mathrm{MHz}, \mathrm{DMSO}-d_{6}\right) \delta 12.45(\mathrm{br} \mathrm{s}, 1 \mathrm{H}), 10.92$ 
(s, 1H), $8.05(\mathrm{~d}, J=0.9 \mathrm{~Hz}, 1 \mathrm{H}), 7.98(\mathrm{~d}, J=8.8 \mathrm{~Hz}, 1 \mathrm{H}), 7.92(\mathrm{~d}, J=7.7 \mathrm{~Hz}, 1 \mathrm{H}), 7.83(\mathrm{~d}$, $J=1.8 \mathrm{~Hz}, 1 \mathrm{H}), 7.82(\mathrm{~d}, J=4.5 \mathrm{~Hz}, 1 \mathrm{H}), 7.55(\mathrm{dd}, J=9.3,1.7 \mathrm{~Hz}, 1 \mathrm{H}), 7.46(\mathrm{~m}, 2 \mathrm{H}), 7.36$ $(\mathrm{dd}, J=2.5,1.2 \mathrm{~Hz}, 1 \mathrm{H}), 7.32(\mathrm{~d}, J=9.0 \mathrm{~Hz}, 1 \mathrm{H}), 7.29(\mathrm{~d}, J=1.0 \mathrm{~Hz}, 1 \mathrm{H}) ; \mathrm{MS}(\mathrm{ESI}) \mathrm{m} / z$ : $440.3[\mathrm{M}-\mathrm{H}]^{-}$.

\section{3,5-dichloro-2-hydroxy-N-(4-(naphthalen-2-yloxy)-3-}

(trifluoromethyl)phenyl)benzamide (6j)-(63\%); $\mathrm{R}_{\mathrm{f}}=0.67\left(\mathrm{CH}_{2} \mathrm{Cl}_{2}\right) ;{ }^{1} \mathrm{H}$ NMR $(300$ MHz, DMSO-d $\left.{ }_{6}\right) \delta 12.40($ br s, 1H), $10.90(\mathrm{~s}, 1 \mathrm{H}), 8.22(\mathrm{~d}, J=2.2 \mathrm{~Hz}, 1 \mathrm{H}), 8.08(\mathrm{~d}, J=2.4$ $\mathrm{Hz}, 1 \mathrm{H}), 8.01(\mathrm{~d}, J=9.1 \mathrm{~Hz}, 1 \mathrm{H}), 7.97(\mathrm{dd}, J=2.3,9.1 \mathrm{~Hz}, 1 \mathrm{H}), 7.95(\mathrm{~d}, J=7.1 \mathrm{~Hz}, 1 \mathrm{H})$, $7.87(\mathrm{~d}, J=7.5 \mathrm{~Hz}, 1 \mathrm{H}), 7.83(\mathrm{~d}, J=2.4 \mathrm{~Hz}, 1 \mathrm{H}), 7.50(\mathrm{td}, J=13.0,6.0 \mathrm{~Hz}, 2 \mathrm{H}), 7.47(\mathrm{~d}, J$ $=1.5 \mathrm{~Hz}, 1 \mathrm{H}), 7.33(\mathrm{dd}, J=8.9,2.5 \mathrm{~Hz}, 1 \mathrm{H}), 7.23(\mathrm{~d}, J=8.9 \mathrm{~Hz}, 1 \mathrm{H}) ; \mathrm{MS}(\mathrm{ESI}) \mathrm{m} / z: 490.3$ $[\mathrm{M}-\mathrm{H}]^{-}$.

\section{3,5-dichloro-2-hydroxy-N-(3-methyl-4-(naphthalen-2-yloxy)phenyl)benzamide} (6k)—(64\%); $\mathrm{R}_{\mathrm{f}}=0.64\left(\mathrm{CH}_{2} \mathrm{Cl}_{2}\right) ;{ }^{1} \mathrm{H}$ NMR $\left(300 \mathrm{MHz}\right.$, DMSO- $\left.d_{6}\right) \delta 12.80(\mathrm{br} \mathrm{s}, 1 \mathrm{H})$, $10.70(\mathrm{~s}, 1 \mathrm{H}), 8.14(\mathrm{~d}, J=1.9 \mathrm{~Hz}, 1 \mathrm{H}), 7.96(\mathrm{~d}, J=9.1 \mathrm{~Hz}, 1 \mathrm{H}), 7.90(\mathrm{~d}, J=7.9 \mathrm{~Hz}, 1 \mathrm{H})$, $7.83(\mathrm{~d}, J=2.2 \mathrm{~Hz}, 1 \mathrm{H}), 7.78(\mathrm{~d}, J=8.1 \mathrm{~Hz}, 1 \mathrm{H}), 7.71(\mathrm{~d}, J=1.6 \mathrm{~Hz}, 1 \mathrm{H}), 7.58(\mathrm{dd}, J=8.8$, $2.3 \mathrm{~Hz}, 1 \mathrm{H}), 7.44(\mathrm{dt}, J=15.9,6.9 \mathrm{~Hz}, 2 \mathrm{H}), 7.29(\mathrm{dd}, J=8.9,2.4 \mathrm{~Hz}, 1 \mathrm{H}), 7.15(\mathrm{~d}, J=1.7$ $\mathrm{Hz}, 1 \mathrm{H}), 7.06(\mathrm{~d}, J=8.8 \mathrm{~Hz}, 1 \mathrm{H}), 2.22(\mathrm{~s}, 3 \mathrm{H}) ; \mathrm{MS}(\mathrm{ESI}) \mathrm{m} / z: 436.2[\mathrm{M}-\mathrm{H}]^{-}$.

\section{3,5-dichloro-N-(3-chloro-4-(p-tolyloxy)phenyl)-2-hydroxybenzamide (6I)-} $(51 \%) ; \mathrm{R}_{\mathrm{f}}=0.71\left(\mathrm{CH}_{2} \mathrm{Cl}_{2}\right) ;{ }^{1} \mathrm{H}$ NMR $(300 \mathrm{MHz}, \mathrm{DMSO}-d 6) \delta 12.53(\mathrm{br} \mathrm{s}, 1 \mathrm{H}), 10.69(\mathrm{~s}$, $1 \mathrm{H}), 8.07(\mathrm{~d}, J=2.6 \mathrm{~Hz}, 1 \mathrm{H}), 7.98(\mathrm{~d}, J=2.6 \mathrm{~Hz}, 1 \mathrm{H}), 7.78(\mathrm{~d}, J=2.5 \mathrm{~Hz}, 1 \mathrm{H}), 7.62(\mathrm{dd}, J$ $=8.9,2.6 \mathrm{~Hz}, 1 \mathrm{H}), 7.18(\mathrm{~d}, J=8.5 \mathrm{~Hz}, 2 \mathrm{H}), 7.08(\mathrm{~d}, J=8.9 \mathrm{~Hz}, 1 \mathrm{H}), 6.86(\mathrm{~d}, J=8.5 \mathrm{~Hz}$, 2H), 2.27 (s, 3H); MS (ESI) $m / z: 422.1[\mathrm{M}+\mathrm{H}]^{+}$.

3,5-dichloro-N-(3-chloro-4-phenoxyphenyl)-2-hydroxybenzamide (6m)-(54\%); $\mathrm{R}_{\mathrm{f}}=0.56\left(\mathrm{CH}_{2} \mathrm{Cl}_{2}\right) ;{ }_{1}^{1} \mathrm{H}$ NMR $\left(300 \mathrm{MHz}, \mathrm{DMSO}-d_{6}\right) \delta 12.42(\mathrm{br} \mathrm{s}, 1 \mathrm{H}), 10.79(\mathrm{~s}, 1 \mathrm{H}), 8.06$ $(\mathrm{d}, J=2.9 \mathrm{~Hz}, 1 \mathrm{H}), 8.02(\mathrm{~d}, J=2.8 \mathrm{~Hz}, 1 \mathrm{H}), 7.83(\mathrm{~d}, J=2.8 \mathrm{~Hz}, 1 \mathrm{H}), 7.65(\mathrm{dd}, J=8.9,2.8$ $\mathrm{Hz}, 1 \mathrm{H}), 7.39$ (t, $J=7.7 \mathrm{~Hz}, 2 \mathrm{H}), 7.18(\mathrm{~d}, J=8.8 \mathrm{~Hz}, 1 \mathrm{H}), 7.13(\mathrm{t}, J=7.0 \mathrm{~Hz}, 1 \mathrm{H}), 6.96(\mathrm{~d}$, $J=8.1 \mathrm{~Hz}, 2 \mathrm{H}$ ); MS (ESI) $\mathrm{m} / z: 408.2[\mathrm{M}-\mathrm{H}]^{-}$.

3,5-dichloro-2-hydroxybenzamide (7)-To a stirred solution of ammonium hydroxide ( $2 \mathrm{mmol}, 5$ equiv) in $5 \mathrm{~mL} \mathrm{CH} \mathrm{Cl}_{2}$ was added salicylic acid chloride ( $0.4 \mathrm{mmol}, 1$ equiv), and the reaction mixture was stirred at RT for $30 \mathrm{~min}$. The reaction was monitored by TLC $\left(\mathrm{CH}_{2} \mathrm{Cl}_{2}\right)$ and once completed the mixture was concentrated in vacuo and purified by column chromatography $\left(\mathrm{CH}_{2} \mathrm{Cl}_{2}\right)$ to obtain 7 as a white solid. $(23 \%) ; \mathrm{R}_{\mathrm{f}}=0.60(10 \%$ $\left.\mathrm{MeOH} / \mathrm{CHCl}_{3}\right) ;{ }^{1} \mathrm{H}$ NMR $\left(300 \mathrm{MHz}, \mathrm{DMSO}-d_{6}\right) \delta 14.15(\mathrm{~s}, 1 \mathrm{H}), 8.70(\mathrm{~s}, 1 \mathrm{H}), 8.33(\mathrm{~s}, 1 \mathrm{H})$, $8.00(\mathrm{~d}, J=1.4 \mathrm{~Hz}, 1 \mathrm{H}), 7.77(\mathrm{~d}, J=1.3 \mathrm{~Hz}, 1 \mathrm{H}) ; \mathrm{MS}(\mathrm{ESI}) \mathrm{m} / z: 204.1[\mathrm{M}-\mathrm{H}]^{-}$.

\section{General procedure for the synthesis of compounds $8 \mathrm{a}-8 \mathrm{~h}$}

To a stirred solution of selected anilines $(0.3 \mathrm{mmol})$ in $5 \mathrm{~mL} \mathrm{CH}_{2} \mathrm{Cl}_{2}$ was added salicylic acid chloride ( $0.3 \mathrm{mmol}, 1$ equiv), and the reaction mixture was stirred at RT for $30 \mathrm{~min}$. The reaction was monitored by $\operatorname{TLC}\left(\mathrm{CH}_{2} \mathrm{Cl}_{2}\right)$ and once completed the mixture was concentrated in vacuo and purified by column chromatography $\left(\mathrm{CH}_{2} \mathrm{Cl}_{2}\right)$ to obtain compounds 8a-8h as off-white solids.

3,5-dichloro-N-(3-chloro-4-hydroxyphenyl)-2-hydroxybenzamide (8a)-(58\%); $\mathrm{R}_{\mathrm{f}}=0.13\left(\mathrm{CH}_{2} \mathrm{Cl}_{2}\right) ;{ }^{1} \mathrm{H}$ NMR $(300 \mathrm{MHz}, \mathrm{DMSO}-d 6) \delta 12.91(\mathrm{br} \mathrm{s}, 1 \mathrm{H}), 10.59(\mathrm{~s}, 1 \mathrm{H}), 8.15$ $(\mathrm{d}, J=2.5 \mathrm{~Hz}, 1 \mathrm{H}), 7.81(\mathrm{~d}, J=2.4 \mathrm{~Hz}, 1 \mathrm{H}), 7.73(\mathrm{~d}, J=2.4 \mathrm{~Hz}, 1 \mathrm{H}), 7.43(\mathrm{dd}, J=8.8,2.5$ $\mathrm{Hz}, 1 \mathrm{H}), 7.01(\mathrm{~d}, J=8.8 \mathrm{~Hz}, 1 \mathrm{H}), 4.11(\mathrm{~s}, 1 \mathrm{H}) ; \mathrm{MS}(\mathrm{ESI}): \mathrm{m} / \mathrm{z} 330.3[\mathrm{M} \mathrm{-} \mathrm{H}]^{-}$. 
3,5-dichloro-N-(2-chlorophenyl)-2-hydroxybenzamide (8b)- $(60 \%) ; \mathrm{R}_{\mathrm{f}}=0.75$

$\left(\mathrm{CH}_{2} \mathrm{Cl}_{2}\right) ;{ }^{1} \mathrm{H}$ NMR $\left(300 \mathrm{MHz}, \mathrm{DMSO}-d_{6}\right) \delta 12.82(\mathrm{br} \mathrm{s}, 1 \mathrm{H}), 10.92(\mathrm{~s}, 1 \mathrm{H}), 8.13(\mathrm{~d}, J=2.5$ $\mathrm{Hz}, 1 \mathrm{H}), 7.87(\mathrm{~d}, J=2.5 \mathrm{~Hz}, 1 \mathrm{H}), 7.82(\mathrm{~d}, J=7.9 \mathrm{~Hz}, 1 \mathrm{H}), 7.60(\mathrm{~d}, J=7.9 \mathrm{~Hz}, 1 \mathrm{H}), 7.43(\mathrm{t}$, $J=7.7 \mathrm{~Hz}, 1 \mathrm{H}), 7.33(\mathrm{t}, J=7.6 \mathrm{~Hz}, 1 \mathrm{H})$; MS (ESI) $\mathrm{m} / z: 314.2[\mathrm{M}-\mathrm{H}]^{-}$.

3,5-dichloro-N-(3-chlorophenyl)-2-hydroxybenzamide (8c)-(62\%); $\mathrm{R}_{\mathrm{f}}=0.70$ $\left(\mathrm{CH}_{2} \mathrm{Cl}_{2}\right) ;{ }^{1} \mathrm{H}$ NMR $\left(300 \mathrm{MHz}, \mathrm{DMSO}-d_{6}\right) \delta 12.39$ (br s, $\left.1 \mathrm{H}\right), 10.74(\mathrm{~s}, 1 \mathrm{H}), 8.06(\mathrm{~d}, J=2.5$ $\mathrm{Hz}, 1 \mathrm{H}), 7.87(\mathrm{t}, J=2.0 \mathrm{~Hz}, 1 \mathrm{H}), 7.82(\mathrm{~d}, J=2.5 \mathrm{~Hz}, 1 \mathrm{H}), 7.63(\mathrm{ddd}, J=8.2,1.9,0.9 \mathrm{~Hz}$, $1 \mathrm{H}), 7.44(\mathrm{t}, J=8.1 \mathrm{~Hz}, 1 \mathrm{H}), 7.26$ (ddd, $J=8.0,2.1,0.9 \mathrm{~Hz}, 1 \mathrm{H}) ; \mathrm{MS}(\mathrm{ESI}) \mathrm{m} / z: 314.2[\mathrm{M}-$ $\mathrm{H}]^{-}$.

3,5-dichloro-N-(4-chlorophenyl)-2-hydroxybenzamide (8d)- $(73 \%) ; \mathrm{R}_{\mathrm{f}}=0.70$ $\left(\mathrm{CH}_{2} \mathrm{Cl}_{2}\right) ;{ }^{1} \mathrm{H}$ NMR $\left(300 \mathrm{MHz}, \mathrm{DMSO}-d_{6}\right) \delta 12.53(\mathrm{~s}, 1 \mathrm{H}), 10.72(\mathrm{~s}, 1 \mathrm{H}), 8.11(\mathrm{~d}, J=2.5$ $\mathrm{Hz}, 1 \mathrm{H}), 7.82(\mathrm{~d}, J=2.4 \mathrm{~Hz}, 1 \mathrm{H}), 7.73(\mathrm{~d}, J=8.9 \mathrm{~Hz}, 2 \mathrm{H}), 7.47(\mathrm{~d}, J=8.9 \mathrm{~Hz}, 2 \mathrm{H}) ; \mathrm{MS}$ (ESI) $m / z: 314.2[\mathrm{M}-\mathrm{H}]^{-} .{ }^{1} \mathrm{H}$ NMR $(300 \mathrm{MHz}$,

3,5-dichloro-2-hydroxy-N-o-tolylbenzamide (8e)-(57\%); $\mathrm{R}_{\mathrm{f}}=0.69\left(\mathrm{CH}_{2} \mathrm{Cl}_{2}\right)$; DMSO- $\left.d_{6}\right) \delta 13.10(\mathrm{br} \mathrm{s}, 1 \mathrm{H}), 10.57(\mathrm{~s}, 1 \mathrm{H}), 8.17(\mathrm{~d}, J=1.6 \mathrm{~Hz}, 1 \mathrm{H}), 7.85(\mathrm{~d}, J=1.0 \mathrm{~Hz}$, $1 \mathrm{H}), 7.38(\mathrm{~d}, J=6.6 \mathrm{~Hz}, 1 \mathrm{H}), 7.32(\mathrm{~d}, J=6.7 \mathrm{~Hz}, 1 \mathrm{H}), 7.25(\mathrm{~m}, 2 \mathrm{H}), 2.24(\mathrm{~s}, 3 \mathrm{H}) ;$ MS (ESI) $m / z: 294.3[\mathrm{M}-\mathrm{H}]^{-} .{ }^{1} \mathrm{H}$ NMR $(300 \mathrm{MHz}$,

3,5-dichloro-2-hydroxy- $\mathrm{N}$-m-tolylbenzamide (8f)-(71\%); $\mathrm{R}_{\mathrm{f}}=0.74\left(\mathrm{CH}_{2} \mathrm{Cl}_{2}\right)$; DMSO- $\left.d_{6}\right) \delta 12.81(\mathrm{br} \mathrm{s}, 1 \mathrm{H}), 10.59(\mathrm{~s}, 1 \mathrm{H}), 8.17(\mathrm{~d}, J=2.2 \mathrm{~Hz}, 1 \mathrm{H}), 7.82(\mathrm{~d}, J=2.2 \mathrm{~Hz}$, $1 \mathrm{H}), 7.53(\mathrm{~s}, 1 \mathrm{H}), 7.49(\mathrm{~d}, J=8.2 \mathrm{~Hz}, 1 \mathrm{H}), 7.29(\mathrm{t}, J=7.7 \mathrm{~Hz}, 1 \mathrm{H}), 7.02(\mathrm{~d}, J=7.1 \mathrm{~Hz}, 1 \mathrm{H})$, 2.33 (s, 3H); MS (ESI) $m / z: 294.2[\mathrm{M} \mathrm{-} \mathrm{H}]^{-} .{ }^{1} \mathrm{H}$ NMR (300 MHz,

3,5-dichloro-2-hydroxy-N-p-tolylbenzamide (8g)-(66\%); $\mathrm{R}_{\mathrm{f}}=0.69\left(\mathrm{CH}_{2} \mathrm{Cl}_{2}\right)$; DMSO- $\left.d_{6}\right) \delta 12.88(\mathrm{br} \mathrm{s}, 1 \mathrm{H}), 10.56(\mathrm{~s}, 1 \mathrm{H}), 8.18(\mathrm{~d}, J=2.2 \mathrm{~Hz}, 1 \mathrm{H}), 7.84(\mathrm{~d}, J=2.3 \mathrm{~Hz}$, $1 \mathrm{H}), 7.38(\mathrm{~d}, J=6.6 \mathrm{~Hz}, 1 \mathrm{H}), 7.31(\mathrm{~d}, J=2.9 \mathrm{~Hz}, 1 \mathrm{H}), 7.25(\mathrm{dd}, J=6.4,3.4 \mathrm{~Hz}, 2 \mathrm{H}), 2.24$ (s, 3H); MS (ESI) $m / z: 294.3[\mathrm{M}-1]^{-}$.

3,5-dichloro-2-hydroxy-N-benzamide (8h)-(66\%); $\mathrm{R}_{\mathrm{f}}=0.69\left(\mathrm{CH}_{2} \mathrm{Cl}_{2}\right) ;{ }^{1} \mathrm{H} \mathrm{NMR}$ $\left(300 \mathrm{MHz}, \mathrm{DMSO}-d_{6}\right) \delta 12.78$ (br s, $\left.1 \mathrm{H}\right), 10.70(\mathrm{~s}, 1 \mathrm{H}), 8.13(\mathrm{~d}, J=2.2 \mathrm{~Hz}, 1 \mathrm{H}), 7.82$ (d, $J$ $=2.3 \mathrm{~Hz}, 1 \mathrm{H}), 7.68(\mathrm{~d}, J=8.4 \mathrm{~Hz}, 2 \mathrm{H}), 7.41(\mathrm{t}, J=7.8 \mathrm{~Hz}, 2 \mathrm{H}), 7.20(\mathrm{t}, J=7.5 \mathrm{~Hz}, 1 \mathrm{H})$; MS (ESI) $m / z: 280.2[\mathrm{M} \mathrm{-} \mathrm{1]-.}$

2,4-dichloro-6-((3-chloro-4-(naphthalen-2-yloxy)phenylimino)methyl)phenol (9) - To a stirred solution of $100 \mathrm{mg}(0.37 \mathrm{mmol}) \mathbf{3 a}$ in $10 \mathrm{~mL}$ ethanol was added $140 \mathrm{mg}(0.74$ mmol, 2 equiv) 3,5-dichloro-hydroxy benzaldehyde dissolved in $2 \mathrm{~mL}$ methanol and the reaction mixture was left stirring until a bright orange precipitate formed. The reaction was monitored by TLC $\left(\mathrm{CH}_{2} \mathrm{Cl}_{2}\right)$ and once completed the mixture was chilled to $4^{\circ} \mathrm{C}$. The precipitate was filtered and washed twice with $10 \mathrm{~mL}$ ethanol to obtain 9 as an orange solid. (90\%); $\mathrm{R}_{\mathrm{f}}=0.83\left(\mathrm{CH}_{2} \mathrm{Cl}_{2}\right) ;{ }^{1} \mathrm{H}$ NMR (300 MHz, DMSO- $\left.d_{6}\right) \delta 13.98(\mathrm{~s}, 1 \mathrm{H}), 9.09(\mathrm{~s}, 1 \mathrm{H})$, $8.01(\mathrm{~d}, J=9.7 \mathrm{~Hz}, 1 \mathrm{H}), 7.94(\mathrm{~d}, J=7.9 \mathrm{~Hz}, 1 \mathrm{H}), 7.90(\mathrm{~d}, J=2.5 \mathrm{~Hz}, 1 \mathrm{H}), 7.84(\mathrm{~d}, J=7.8$ $\mathrm{Hz}, 1 \mathrm{H}), 7.78(\mathrm{~d}, J=2.6 \mathrm{~Hz}, 1 \mathrm{H}), 7.74(\mathrm{~d}, J=2.6 \mathrm{~Hz}, 1 \mathrm{H}), 7.55(\mathrm{dd}, J=8.7,2.5 \mathrm{~Hz}, 1 \mathrm{H})$, $7.48(\mathrm{~m}, 2 \mathrm{H}), 7.36(\mathrm{dd}, J=6.6,2.8 \mathrm{~Hz}, 1 \mathrm{H}), 7.35(\mathrm{~d}, J=3.1 \mathrm{~Hz}, 1 \mathrm{H}), 7.31(\mathrm{~d}, J=8.7 \mathrm{~Hz}$, 1H); MS (ESI) $m / z: 440.3[\mathrm{M} \mathrm{-} \mathrm{H}]^{-}$.

\section{2,4-dichloro-6-((3-chloro-4-(naphthalen-2-yloxy)phenylamino)methyl)phenol} (10) - To a stirred solution of $50 \mathrm{mg}(0.113 \mathrm{mmol}) 9$ in $5 \mathrm{~mL}$ methanol was added $113 \mu \mathrm{L}$ of $5 \mathrm{M}$ sodium cyanoborohydride $\left(0.565 \mathrm{mmol}, 5\right.$ equiv) and left stirring for $24 \mathrm{~h}$ at $70^{\circ} \mathrm{C}$. The reaction was monitored by $\mathrm{TLC}\left(\mathrm{CH}_{2} \mathrm{Cl}_{2}\right)$ and once completed routine aqueous workup 
was performed. The organic phase was concentrated and purified by column chromatography $\left(\mathrm{CH}_{2} \mathrm{Cl}_{2}\right)$ to obtain $\mathbf{1 0}$ as an orange solid. $(40 \%) ; \mathrm{R}_{\mathrm{f}}=0.76\left(\mathrm{CH}_{2} \mathrm{Cl}_{2}\right) ;{ }^{1} \mathrm{H}$ NMR $\left(300 \mathrm{MHz}\right.$, DMSO- $\left.d_{6}\right) \delta 9.78(\mathrm{~s}, 1 \mathrm{H}), 7.91(\mathrm{~d}, J=9.0 \mathrm{~Hz}, 1 \mathrm{H}), 7.87(\mathrm{~d}, J=8.0 \mathrm{~Hz}$, $1 \mathrm{H}), 7.74(\mathrm{~d}, J=7.8 \mathrm{~Hz}, 1 \mathrm{H}), 7.42(\mathrm{~d}, J=2.5 \mathrm{~Hz}, 1 \mathrm{H}), 7.41(\mathrm{~m}, 2 \mathrm{H}), 7.25(\mathrm{~d}, J=2.4 \mathrm{~Hz}$, $1 \mathrm{H}), 7.23(\mathrm{dd}, J=6.3,2.6 \mathrm{~Hz}, 1 \mathrm{H}), 7.07(\mathrm{~d}, J=8.6 \mathrm{~Hz}, 1 \mathrm{H}), 7.02(\mathrm{~d}, J=2.4 \mathrm{~Hz}, 1 \mathrm{H}), 6.77$ $(\mathrm{d}, J=2.7 \mathrm{~Hz}, 1 \mathrm{H}), 6.62(\mathrm{dd}, J=8.9,2.7 \mathrm{~Hz}, 1 \mathrm{H}), 6.49(\mathrm{t}, J=5.8 \mathrm{~Hz}, 1 \mathrm{H}), 4.29(\mathrm{~d}, J=5.6$ $\mathrm{Hz}, 2 \mathrm{H})$; MS (ESI) $m / z: 442.1[\mathrm{M} \mathrm{-} \mathrm{H}]^{-}$.

3-chloro-N-methyl-4-(naphthalen-2-yloxy)aniline (11)—To $100 \mathrm{mg}(0.37 \mathrm{mmol})$ 3a and $510 \mathrm{mg}$ ( $3.7 \mathrm{mmol}, 10$ equiv) $\mathrm{K}_{2} \mathrm{CO}_{3}$ in $10 \mathrm{~mL}$ acetone was added $23 \mu \mathrm{L}(0.37 \mathrm{mmol})$ iodomethane and refluxed for $1 \mathrm{~h}$. Every hour 1 equivalent of iodomethane was added and monitored by TLC until the starting material was consumed. The solvent was removed in vacuo, and routine aqueous workup was performed. The mixture was concentrated and purified by column chromatography $\left(\mathrm{CH}_{2} \mathrm{Cl}_{2}\right)$ to obtain $\mathbf{1 1}$ as a white solid. $(29 \%) ; \mathrm{R}_{\mathrm{f}}=$ $0.58\left(\mathrm{CH}_{2} \mathrm{Cl}_{2}\right) ;{ }^{1} \mathrm{H}$ NMR $\left(300 \mathrm{MHz}, \mathrm{DMSO}-d_{6}\right) \delta 7.91(\mathrm{~d}, J=9.1 \mathrm{~Hz}, 1 \mathrm{H}), 7.87(\mathrm{~d}, J=8.2$ $\mathrm{Hz}, 1 \mathrm{H}), 7.75(\mathrm{~d}, J=7.9 \mathrm{~Hz}, 1 \mathrm{H}), 7.41(\mathrm{~m}, 2 \mathrm{H}), 7.25(\mathrm{dd}, J=8.9,2.5 \mathrm{~Hz}, 1 \mathrm{H}), 7.07(\mathrm{~d}, J=$ $8.8 \mathrm{~Hz}, 1 \mathrm{H}), 7.00(\mathrm{~d}, J=2.4 \mathrm{~Hz}, 1 \mathrm{H}), 6.69(\mathrm{~d}, J=2.7 \mathrm{~Hz}, 1 \mathrm{H}), 6.59(\mathrm{dd}, J=8.8,2.7 \mathrm{~Hz}$, $1 \mathrm{H}), 5.99(\mathrm{~d}, J=5.0 \mathrm{~Hz}, 1 \mathrm{H}), 2.70(\mathrm{~d}, J=5.0 \mathrm{~Hz}, 3 \mathrm{H})$.

\section{3,5-dichloro-N-(3-chloro-4-(naphthalen-2-yloxy)phenyl)-2-hydroxy- $\mathrm{N}$ -} methylbenzamide (12)-To a stirred solution of $30 \mathrm{mg}(0.106 \mathrm{mmol}) 11$ in $5 \mathrm{~mL} \mathrm{CH} \mathrm{Cl}_{2}$ was added $29 \mathrm{mg}$ ( $0.127 \mathrm{mmol}, 1.2$ equiv) $\mathbf{5 a}$ and the mixture was left stirring at RT for 0.5 h. The reaction was monitored by $\mathrm{TLC}\left(\mathrm{CH}_{2} \mathrm{Cl}_{2}\right)$ and once completed routine aqueous workup was performed, and the organic phase was concentrated and purified by column chromatography $\left(\mathrm{CH}_{2} \mathrm{Cl}_{2}\right)$ to obtain 9 as a white solid. $(48 \%) ; \mathrm{R}_{\mathrm{f}}=0.42\left(\mathrm{CH}_{2} \mathrm{Cl}_{2}\right) ;{ }^{1} \mathrm{H} \mathrm{NMR}$ $\left(300 \mathrm{MHz}\right.$, DMSO- $\left.d_{6}\right) \delta 10.28(\mathrm{~s}, 1 \mathrm{H}), 7.96(\mathrm{~d}, J=8.9 \mathrm{~Hz}, 1 \mathrm{H}), 7.92(\mathrm{~d}, J=7.9 \mathrm{~Hz}, 1 \mathrm{H})$, $7.76(\mathrm{~d}, J=8.2 \mathrm{~Hz}, 1 \mathrm{H}), 7.62(\mathrm{~d}, J=2.4 \mathrm{~Hz}, 1 \mathrm{H}), 7.51(\mathrm{~d}, J=2.4 \mathrm{~Hz}, 1 \mathrm{H}), 7.48(\mathrm{dt}, J=$ $19.9,6.7 \mathrm{~Hz}, 2 \mathrm{H}), 7.24(\mathrm{~d}, J=3.3 \mathrm{~Hz}, 1 \mathrm{H}), 7.22(\mathrm{dd}, J=11.1,2.5 \mathrm{~Hz}, 1 \mathrm{H}), 7.20(\mathrm{~d}, J=1.7$ $\mathrm{Hz}, 1 \mathrm{H}), 7.13$ (dd, $J=8.6,2.4 \mathrm{~Hz}, 1 \mathrm{H}), 7.08(\mathrm{~d}, J=1.3 \mathrm{~Hz}, 1 \mathrm{H}), 3.35$ (s, 3H); MS (ESI): m/ $\mathrm{z} 470.1[\mathrm{M}-\mathrm{H}]^{-}$.

\section{Acknowledgments}

This research was supported in part by NIH grants CA43894, CA27502, and CA090085 (MKJ), a grant from Telik Inc., and a pre-doctoral fellowship from the ACS Division of Medicinal Chemistry sponsored by Amgen (to JDS). The authors thank Trevigen Inc. for providing PARP-1 and PAR ELISA kits. MKJ serves as a consultant to Trevigen.

\section{Abbreviations}

$\begin{array}{ll}\text { ADP } & \text { adenosine diphosphate } \\ \text { PAR } & \text { poly(ADP-ribose) } \\ \text { PARP } & \text { poly(ADP-ribose) polymerase } \\ \text { BRCA1/2 } & \text { breast cancer susceptibility protein } 1 / 2 \\ \text { PARG } & \text { poly(ADP-ribose) glycohydrolase } \\ \text { NAD }^{+} & \text {the oxidized form of nicotinamide adenine dinucleotide } \\ \text { NAD(H) } & \text { the total cellular pool of nicotinamide adenine dinucleotide, both oxidized } \\ & \text { and reduced forms } \\ \text { TRAP } & \text { Target-related Affinity Profiling }\end{array}$




$\begin{array}{ll}\text { IC50 } & \text { half maximal inhibitory concentration } \\ \text { HBD } & \text { hydrogen bond donor } \\ \text { HBA } & \text { hydrogen bond acceptor } \\ \text { SAR } & \text { structure-activity relationship } \\ \text { ADP-HPD } & \text { adenosine 5'-diphosphate (hydroxymethyl) pyrrolidinediol } \\ \text { MNNG } & \text { N-methyl-N'-nitro-N-nitrosoguanidine }\end{array}$

\section{References}

1. Diefenbach J, Burkle A. Introduction to poly(ADP-ribose) metabolism. Cell Mol Life Sci. 2005; 62(7-8):721-730. [PubMed: 15868397]

2. Juarez-Salinas H, Sims JL, Jacobson MK. Poly(ADP-ribose) levels in carcinogen-treated cells. Nature. 1979; 282(5740):740-741. [PubMed: 229416]

3. Hottiger MO, Hassa PO, Luscher B, Schuler H, Koch-Nolte F. Toward a unified nomenclature for mammalian ADP-ribosyltransferases. Trends Biochem Sci. 2010; 35(4):208-219. [PubMed: 20106667]

4. Davidovic L, Vodenicharov M, Affar EB, Poirier GG. Importance of poly(ADP-ribose) glycohydrolase in the control of poly(ADP-ribose) metabolism. Exp Cell Res. 2001; 268(1):7-13. [PubMed: 11461113]

5. Braun SA, Panzeter PL, Collinge MA, Althaus FR. Endoglycosidic cleavage of branched polymers by poly(ADP-ribose) glycohydrolase. Eur J Biochem. 1994; 220(2):369-375. [PubMed: 8125093]

6. Alvarez-Gonzalez R, Jacobson MK. Characterization of polymers of adenosine diphosphate ribose generated in vitro and in vivo. Biochemistry. 1987; 26(11):3218-3224. [PubMed: 3038179]

7. D’Amours D, Desnoyers S, D’Silva I, Poirier GG. Poly(ADP-ribosyl)ation reactions in the regulation of nuclear functions. Biochem J. 1999; 342 ( Pt 2):249-268. [PubMed: 10455009]

8. Jacobson MK, Levi V, Juarez-Salinas H, Barton RA, Jacobson EL. Effect of carcinogenic N-alkyl$\mathrm{N}$-nitroso compounds on nicotinamide adenine dinucleotide metabolism. Cancer Res. 1980; 40(6): 1797-1802. [PubMed: 6245804]

9. Berger NA. Poly(ADP-ribose) in the cellular response to DNA damage. Radiat Res. 1985; 101(1):415. [PubMed: 3155867]

10. Curtin NJ. PARP inhibitors for cancer therapy. Expert Rev Mol Med. 2005; 7(4):1-20. [PubMed: 15836799]

11. Ferraris DV. Evolution of poly(ADP-ribose) polymerase-1 (PARP-1) inhibitors. From concept to clinic. J Med Chem. 2010; 53(12):4561-4584. [PubMed: 20364863]

12. Rouleau M, Patel A, Hendzel MJ, Kaufmann SH, Poirier GG. PARP inhibition: PARP1 and beyond. Nat Rev Cancer. 2010; 10(4):293-301. [PubMed: 20200537]

13. Sunderland PT, Dhami A, Mahon MF, Jones LA, Tully SR, Lloyd MD, Thompson AS, Javaid H, Martin NM, Threadgill MD. Synthesis of 4-alkyl-, 4-aryl- and 4-arylamino-5-aminoisoquinolin-1ones and identification of a new PARP-2 selective inhibitor. Org Biomol Chem. 2011; 9(3):881891. [PubMed: 21127791]

14. Plummer ER. Inhibition of poly(ADP-ribose) polymerase in cancer. Curr Opin Pharmacol. 2006; 6(4):364-368. [PubMed: 16753340]

15. Bryant HE, Schultz N, Thomas HD, Parker KM, Flower D, Lopez E, Kyle S, Meuth M, Curtin NJ, Helleday T. Specific killing of BRCA2-deficient tumours with inhibitors of poly(ADP-ribose) polymerase. Nature. 2005; 434(7035):913-917. [PubMed: 15829966]

16. Farmer H, McCabe N, Lord CJ, Tutt AN, Johnson DA, Richardson TB, Santarosa M, Dillon KJ, Hickson I, Knights C, Martin NM, Jackson SP, Smith GC, Ashworth A. Targeting the DNA repair defect in BRCA mutant cells as a therapeutic strategy. Nature. 2005; 434(7035):917-921. [PubMed: 15829967] 
17. Min W, Wang ZQ. Poly (ADP-ribose) glycohydrolase (PARG) and its therapeutic potential. Front Biosci. 2009; 14:1619-1626. [PubMed: 19273151]

18. Koh DW, Lawler AM, Poitras MF, Sasaki M, Wattler S, Nehls MC, Stoger T, Poirier GG, Dawson VL, Dawson TM. Failure to degrade poly(ADP-ribose) causes increased sensitivity to cytotoxicity and early embryonic lethality. Proc Natl Acad Sci U S A. 2004; 101(51):17699-17704. [PubMed: 15591342]

19. Cortes U, Tong WM, Coyle DL, Meyer-Ficca ML, Meyer RG, Petrilli V, Herceg Z, Jacobson EL, Jacobson MK, Wang ZQ. Depletion of the 110-kilodalton isoform of poly(ADP-ribose) glycohydrolase increases sensitivity to genotoxic and endotoxic stress in mice. Mol Cell Biol. 2004; 24(16):7163-7178. [PubMed: 15282315]

20. Gao H, Coyle DL, Meyer-Ficca ML, Meyer RG, Jacobson EL, Wang ZQ, Jacobson MK. Altered poly(ADP-ribose) metabolism impairs cellular responses to genotoxic stress in a hypomorphic mutant of poly(ADP-ribose) glycohydrolase. Exp Cell Res. 2007; 313(5):984-996. [PubMed: 17276427]

21. Blenn C, Althaus FR, Malanga M. Poly(ADP-ribose) glycohydrolase silencing protects against H2O2-induced cell death. Biochem J. 2006; 396(3):419-429. [PubMed: 16526943]

22. Cohausz O, Blenn C, Malanga M, Althaus FR. The roles of poly(ADP-ribose)-metabolizing enzymes in alkylation-induced cell death. Cell Mol Life Sci. 2008; 65(4):644-655. [PubMed: 18202825]

23. Burns DM, Ying W, Kauppinen TM, Zhu K, Swanson RA. Selective down-regulation of nuclear poly(ADP-ribose) glycohydrolase. PLoS One. 2009; 4(3):e4896. [PubMed: 19319190]

24. Tang JB, Svilar D, Trivedi RN, Wang XH, Goellner EM, Moore B, Hamilton RL, Banze LA, Brown AR, Sobol RW. N-methylpurine DNA glycosylase and DNA polymerase \{beta\} modulate BER inhibitor potentiation of glioma cells to temozolomide. Neuro Oncol. 2011; 13(5):471-486. [PubMed: 21377995]

25. Tanuma S, Sakagami H, Endo H. Inhibitory effect of tannin on poly(ADP-ribose) glycohydrolase from human placenta. Biochem Int. 1989; 18(4):701-708. [PubMed: 2764971]

26. Bakondi E, Bai P, Erdelyi K, Szabo C, Gergely P, Virag L. Cytoprotective effect of gallotannin in oxidatively stressed HaCaT keratinocytes: the role of poly(ADP-ribose) metabolism. Exp Dermatol. 2004; 13(3):170-178. [PubMed: 14987257]

27. Ying W, Sevigny MB, Chen Y, Swanson RA. Poly(ADP-ribose) glycohydrolase mediates oxidative and excitotoxic neuronal death. Proc Natl Acad Sci U S A. 2001; 98(21):12227-12232. [PubMed: 11593040]

28. Tavassoli M, Tavassoli MH, Shall S. Effect of DNA intercalators on poly(ADP-ribose) glycohydrolase activity. Biochim Biophys Acta. 1985; 827(3):228-234. [PubMed: 3838253]

29. Ramsinghani S, Koh DW, Ame JC, Strohm M, Jacobson MK, Slama JT. Syntheses of photoactive analogues of adenosine diphosphate (hydroxymethyl)pyrrolidinediol and photoaffinity labeling of poly(ADP-ribose) glycohydrolase. Biochemistry. 1998; 37(21):7801-7812. [PubMed: 9601041]

30. Slama JT, Aboul-Ela N, Goli DM, Cheesman BV, Simmons AM, Jacobson MK. Specific inhibition of poly(ADP-ribose) glycohydrolase by adenosine diphosphate (hydroxymethyl)pyrrolidinediol. J Med Chem. 1995; 38(2):389-393. [PubMed: 7830282]

31. Slama JT, Aboul-Ela N, Jacobson MK. Mechanism of inhibition of poly(ADP-ribose) glycohydrolase by adenosine diphosphate (hydroxymethyl)pyrrolidinediol. J Med Chem. 1995; 38(21):4332-4336. [PubMed: 7473561]

32. Li, J.; Ferraris, D.; Kletzly, P.; Li, W.; Wang, E.; Xing, A.; Xu, W.; Zhang, J. Symmetrically disubstituted aromatic compounds and pharmaceutical compositions for inhibiting poly(ADPribose) glycohydrolase, and methods for their use. WO 2002. p. 02057211

33. Falsig J, Christiansen SH, Feuerhahn S, Burkle A, Oei SL, Keil C, Leist M. Poly(ADP-ribose) glycohydrolase as a target for neuroprotective intervention: assessment of currently available pharmacological tools. Eur J Pharmacol. 2004; 497(1):7-16. [PubMed: 15321729]

34. Labieniec M, Gabryelak T, Falcioni G. Antioxidant and pro-oxidant effects of tannins in digestive cells of the freshwater mussel Unio tumidus. Mutat Res. 2003; 539(1-2):19-28. [PubMed: 12948811] 
35. Blenn C, Wyrsch P, Althaus FR. The Ups and Downs of Tannins as Inhibitors of Poly(ADPRibose)glycohydrolase. Molecules. 2011; 16(2):1854-1877. [PubMed: 21343889]

36. Beroza P, Damodaran K, Lum RT. Target-related affinity profiling: Telik's lead discovery technology. Curr Top Med Chem. 2005; 5(4):371-381. [PubMed: 15892680]

37. Suezawa H, Hirota M, Yuzuri T, Hamada Y, Takeuchi I, Sugiura M. Studies on the Conformations of Antimicrobial Salicylanilide Derivatives by Spectroscopy. Bull Chem Soc Jpn. 2000; 73:23352339.

38. Botta D, Jacobson MK. Identification of a regulatory segment of poly(ADP-ribose) glycohydrolase. Biochemistry. 2010; 49(35):7674-7682. [PubMed: 20684510]

39. Rankin PW, Jacobson EL, Benjamin RC, Moss J, Jacobson MK. Quantitative studies of inhibitors of ADP-ribosylation in vitro and in vivo. J Biol Chem. 1989; 264(8):4312-4317. [PubMed: 2538435]

40. Hassa PO, Hottiger MO. The diverse biological roles of mammalian PARPS, a small but powerful family of poly-ADP-ribose polymerases. Front Biosci. 2008; 13:3046-3082. [PubMed: 17981777]

41. Berger NA, Berger SJ. Metabolic consequences of DNA damage: the role of poly (ADP-ribose) polymerase as mediator of the suicide response. Basic Life Sci. 1986; 38:357-363. [PubMed: 2943264]

42. Andrabi SA, Kim NS, Yu SW, Wang H, Koh DW, Sasaki M, Klaus JA, Otsuka T, Zhang Z, Koehler RC, Hurn PD, Poirier GG, Dawson VL, Dawson TM. Poly(ADP-ribose) (PAR) polymer is a death signal. Proc Natl Acad Sci U S A. 2006; 103(48):18308-18313. [PubMed: 17116882]

43. Virag L, Szabo C. The therapeutic potential of poly(ADP-ribose) polymerase inhibitors. Pharmacol Rev. 2002; 54(3):375-429. [PubMed: 12223530]

44. Szabo C. Pharmacological inhibition of poly(ADP-ribose) polymerase in cardiovascular disorders: future directions. Curr Vasc Pharmacol. 2005; 3(3):301-303. [PubMed: 16026326]

45. Sodhi RK, Singh N, Jaggi AS. Poly(ADP-ribose) polymerase-1 (PARP-1) and its therapeutic implications. Vascul Pharmacol. 2010; 53(3-4):77-87. [PubMed: 20633699]

46. Genovese T, Di Paola R, Catalano P, Li JH, Xu W, Massuda E, Caputi AP, Zhang J, Cuzzocrea S. Treatment with a novel poly(ADP-ribose) glycohydrolase inhibitor reduces development of septic shock-like syndrome induced by zymosan in mice. Crit Care Med. 2004; 32(6):1365-1374. [PubMed: 15187521]

47. Lu XC, Massuda E, Lin Q, Li W, Li JH, Zhang J. Post-treatment with a novel PARG inhibitor reduces infarct in cerebral ischemia in the rat. Brain Res. 2003; 978(1-2):99-103. [PubMed: 12834903]

48. Lin W, Ame JC, Aboul-Ela N, Jacobson EL, Jacobson MK. Isolation and characterization of the cDNA encoding bovine poly(ADP-ribose) glycohydrolase. J Biol Chem. 1997; 272(18):1189511901. [PubMed: 9115250]

49. Menard L, Poirier GG. Rapid assay of poly(ADP-ribose) glycohydrolase. Biochem Cell Biol. 1987; 65(7):668-673. [PubMed: 3325077]

50. Jacobson EL, Jacobson MK. Pyridine nucleotide levels as a function of growth in normal and transformed 3T3 cells. Arch Biochem Biophys. 1976; 175(2):627-634. [PubMed: 8713] 


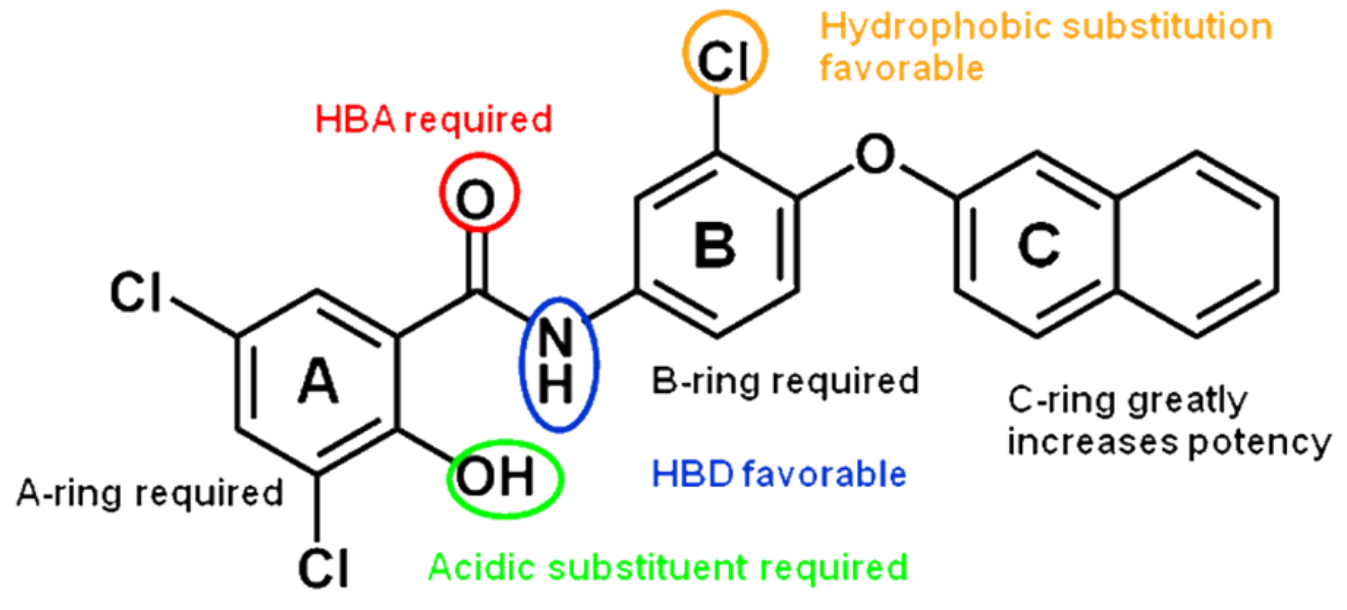

Figure 1.

Key pharmacophoric elements related to PARG inhibition 
A

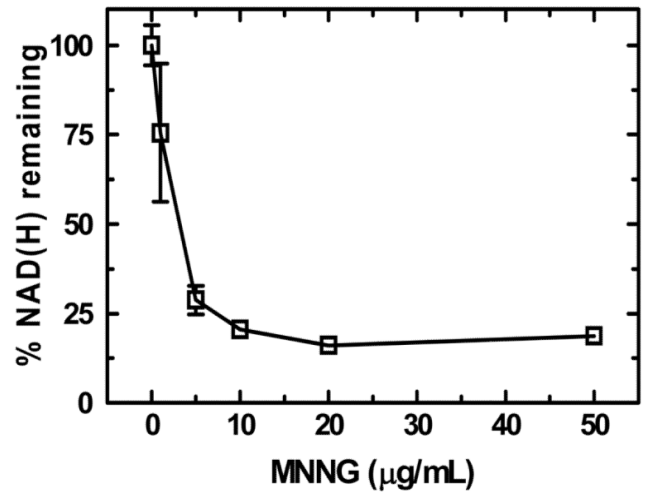

B

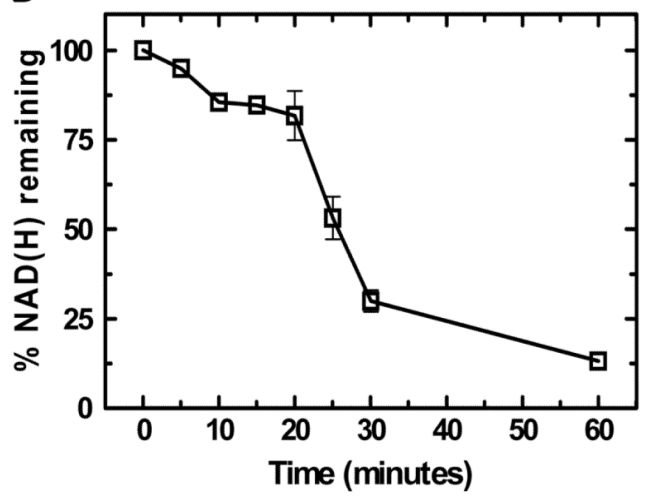

C

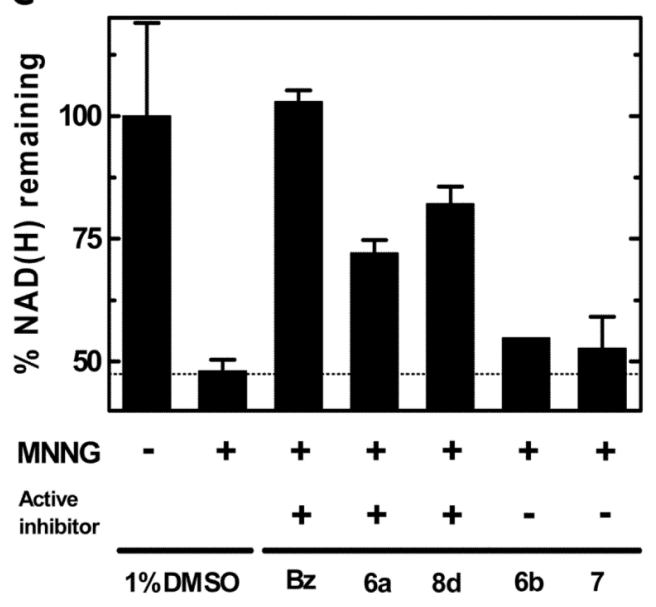

Figure 2.

Depletion of NAD(H) in SCC-25 cells following genotoxic stress: (A) Treatment with varying concentrations of MNNG for 30 minutes; (B) A time course of $\mathrm{NAD}(\mathrm{H})$ levels following treatment with MNNG $(5 \mu \mathrm{g} / \mathrm{mL})$; (C) Effects on $\mathrm{NAD}(\mathrm{H})$ depletion in cells treated with MNNG $(5 \mu \mathrm{g} / \mathrm{mL})$ for 30 minutes, pretreated with $1 \mathrm{mM}$ of benzamide $(\mathrm{Bz}), \mathbf{6 a}$, $8 d, 6 b$, or 7 . 

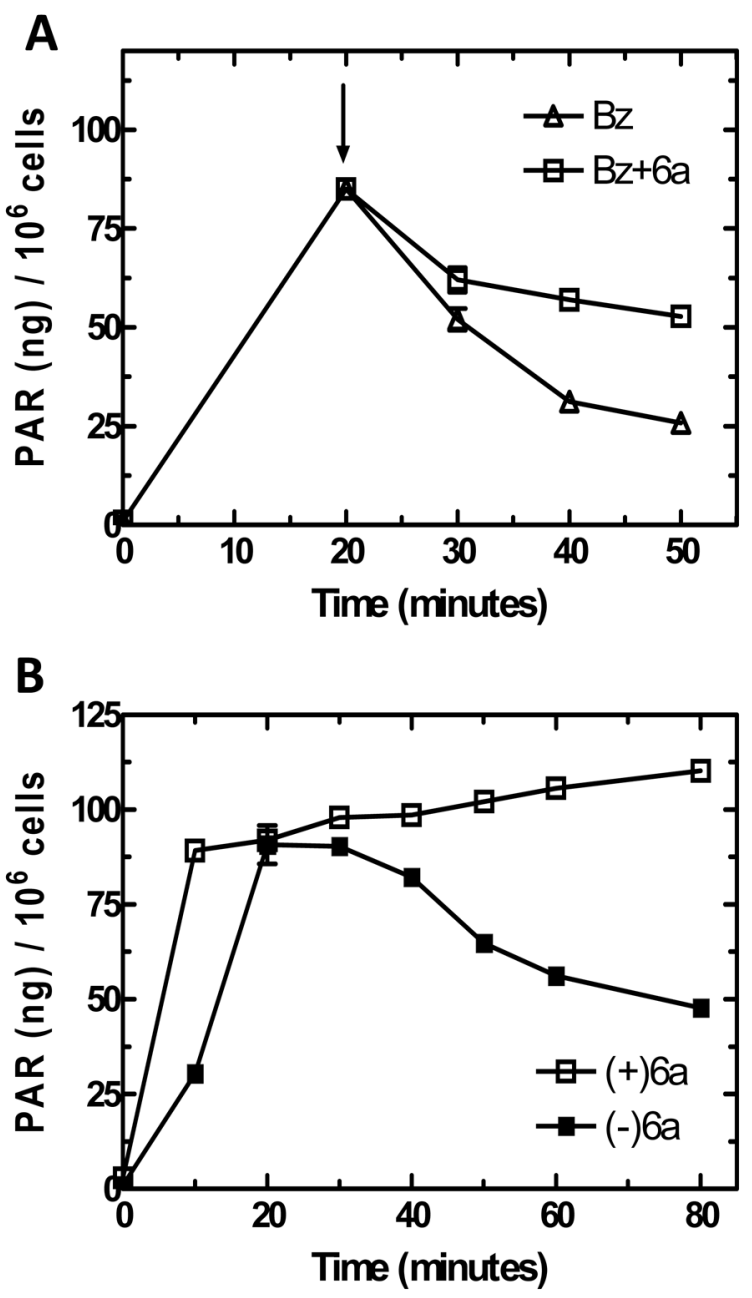

Figure 3.

PAR formation in SCC-25 cells following genotoxic stress: (A) Time course of PAR formation after treatment of MNNG $(5 \mu \mathrm{g} / \mathrm{mL})$. Cells were treated with $1 \mathrm{mM}$ benzamide with compound $\mathbf{6 a}(\square)$ and without compound $\mathbf{6 a}(\Delta)$ at 20 minutes as indicated by the arrow; (B) Time course of PAR formation following treatment of MNNG $(5 \mu \mathrm{g} / \mathrm{mL})$, pretreated with $1 \mathrm{mM}$ compound $\mathbf{6 a}(\square)$ and without pretreatment (a). 

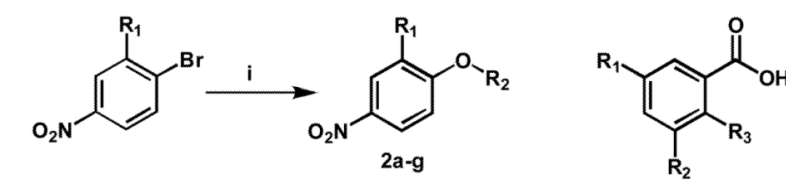

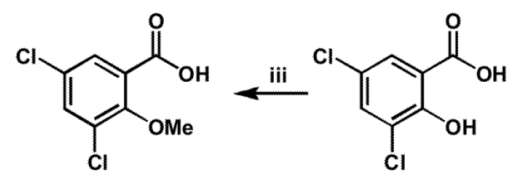
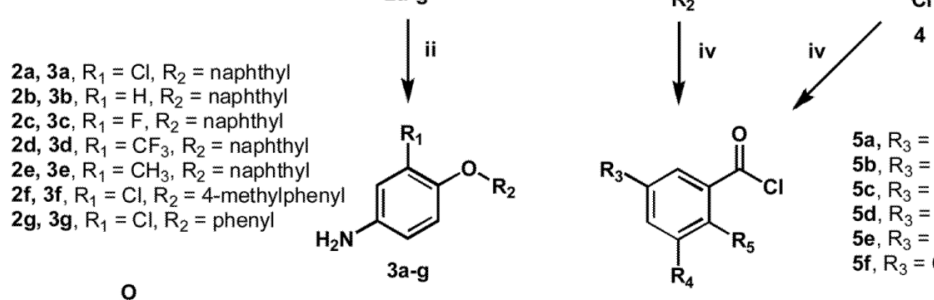

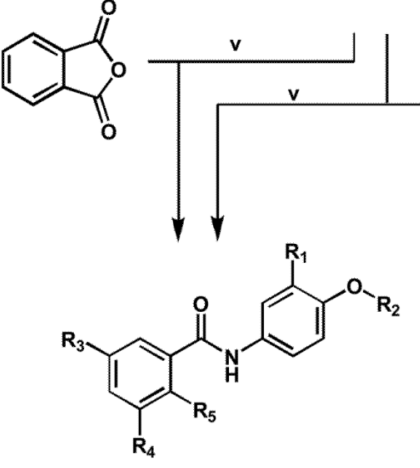

$6 a-m$

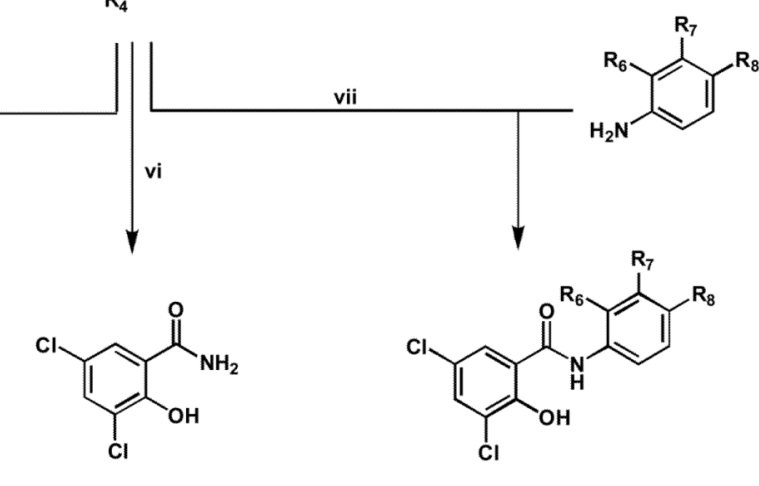

Scheme 1.

Synthesis of A-ring, B-ring, and C-ring substituted analogues. ${ }^{a}$

${ }^{a}$ Reagents and Conditions: (i) $\mathrm{HO}-\mathrm{R}, \mathrm{Cs}_{2} \mathrm{CO}_{3}, 90^{\circ} \mathrm{C}, 24 \mathrm{hrs}$; (ii) $\mathrm{SnCl}_{2}, \mathrm{EtOH}, 70^{\circ} \mathrm{C}, 3 \mathrm{hrs}$; (iii) $\mathrm{CH}_{3} \mathrm{I}$, acetone, $\mathrm{K}_{2} \mathrm{CO}_{3}$, reflux, $3 \mathrm{hrs}$; (iv) $\mathrm{SOCl}_{2}, 100^{\circ} \mathrm{C}, 30 \mathrm{~min}$; (v) $\mathrm{CH}_{2} \mathrm{Cl}_{2}$, RT; (vi) $\mathrm{NH}_{4} \mathrm{OH}, \mathrm{CH}_{2} \mathrm{Cl}_{2}$, RT; (vii) $\mathrm{H}_{2} \mathrm{~N}-\mathrm{R}$, ether, RT. 


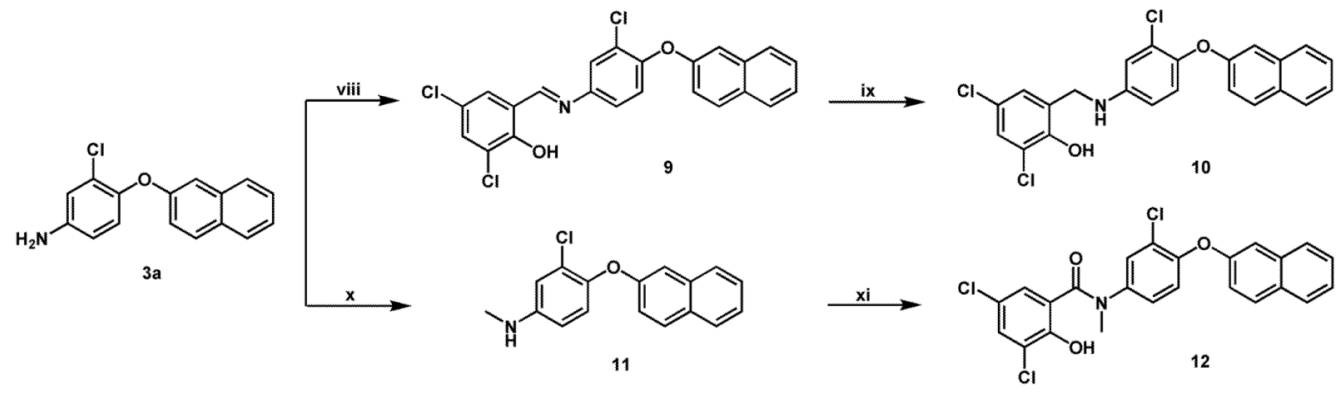

Scheme 2.

Synthesis of linker modified analogues. ${ }^{a}$

${ }^{a}$ Reagents and Conditions: (viii) 3,5-dichloro-salicylaldehyde, EtOH; (ix) $\mathrm{NaCNBH}_{3}, \mathrm{EtOH}$; (x) $\mathrm{CH}_{3} \mathrm{I}$, acetone, $\mathrm{K}_{2} \mathrm{CO}_{3}$, reflux 3 hrs; (xi) 5a, $\mathrm{CH}_{2} \mathrm{Cl}_{2}$, RT. 


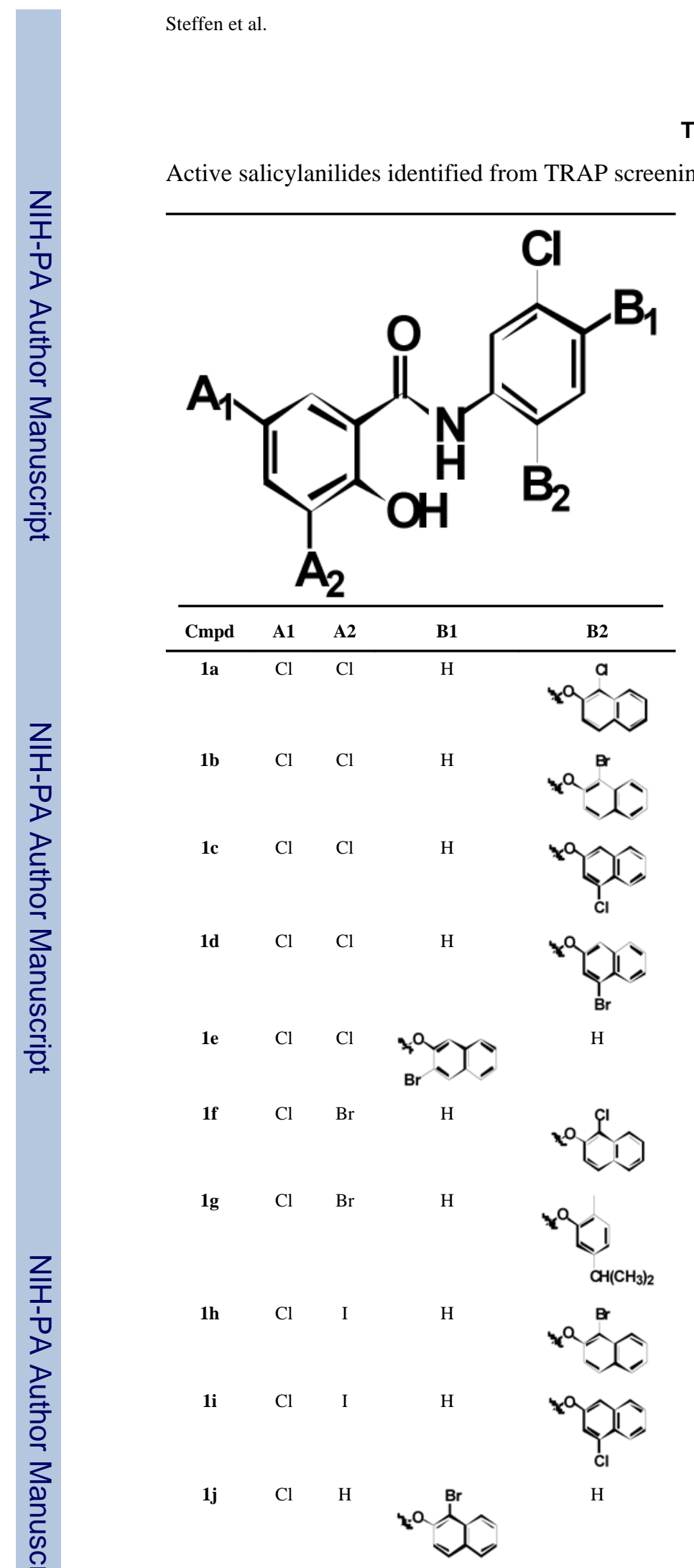

Table 1

Active salicylanilides identified from TRAP screening

$19 \quad \mathrm{Cl} \quad \mathrm{Br} \quad \mathrm{H}$ 


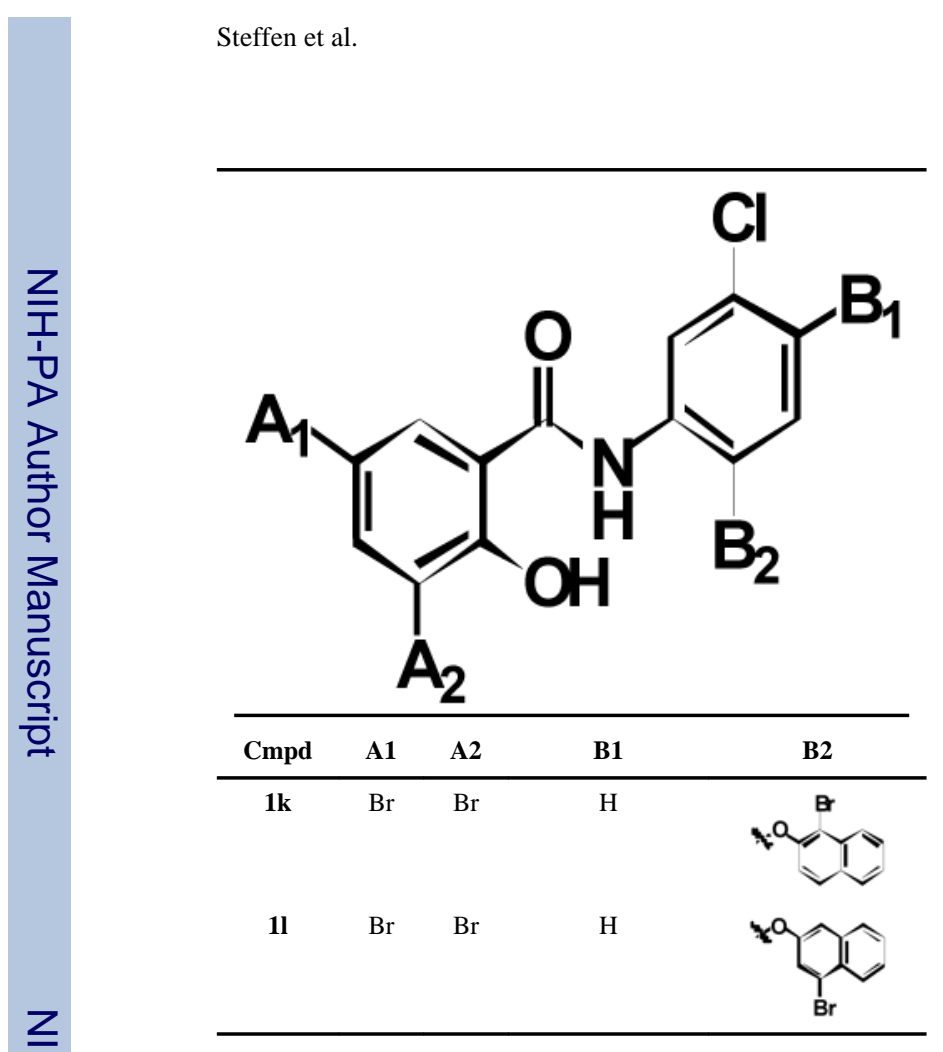


Table 2

SAR of A-ring substituted analogues

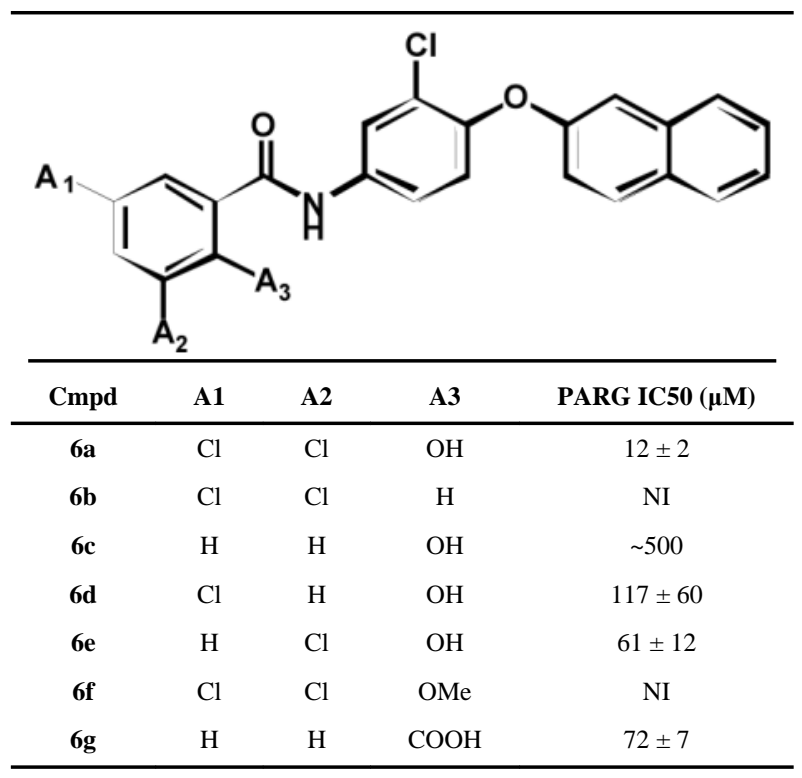

NI (Non inhibitory): no detectable inhibition of PARG up to $500 \mu \mathrm{M}$ 
Table 3

SAR of linker modified analogues

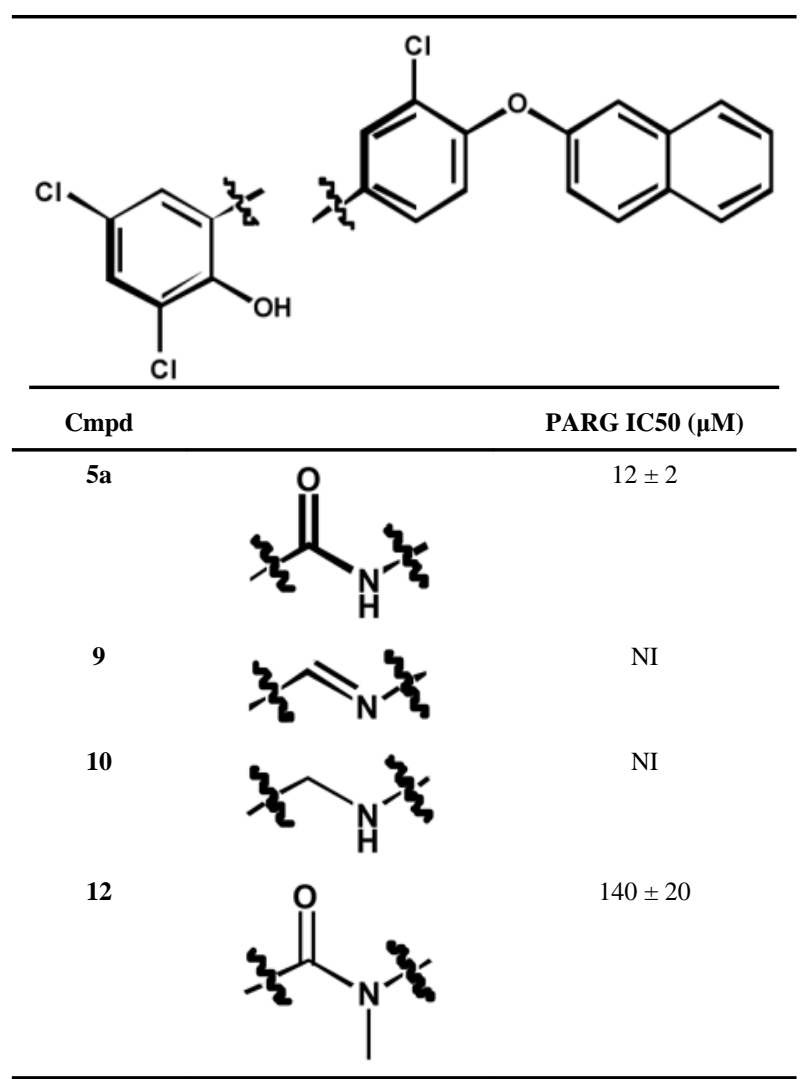

NI (Non inhibitory): no detectable inhibition of PARG up to $500 \mu \mathrm{M}$ 
Table 4

SAR of B-ring and C-ring substituted analogues

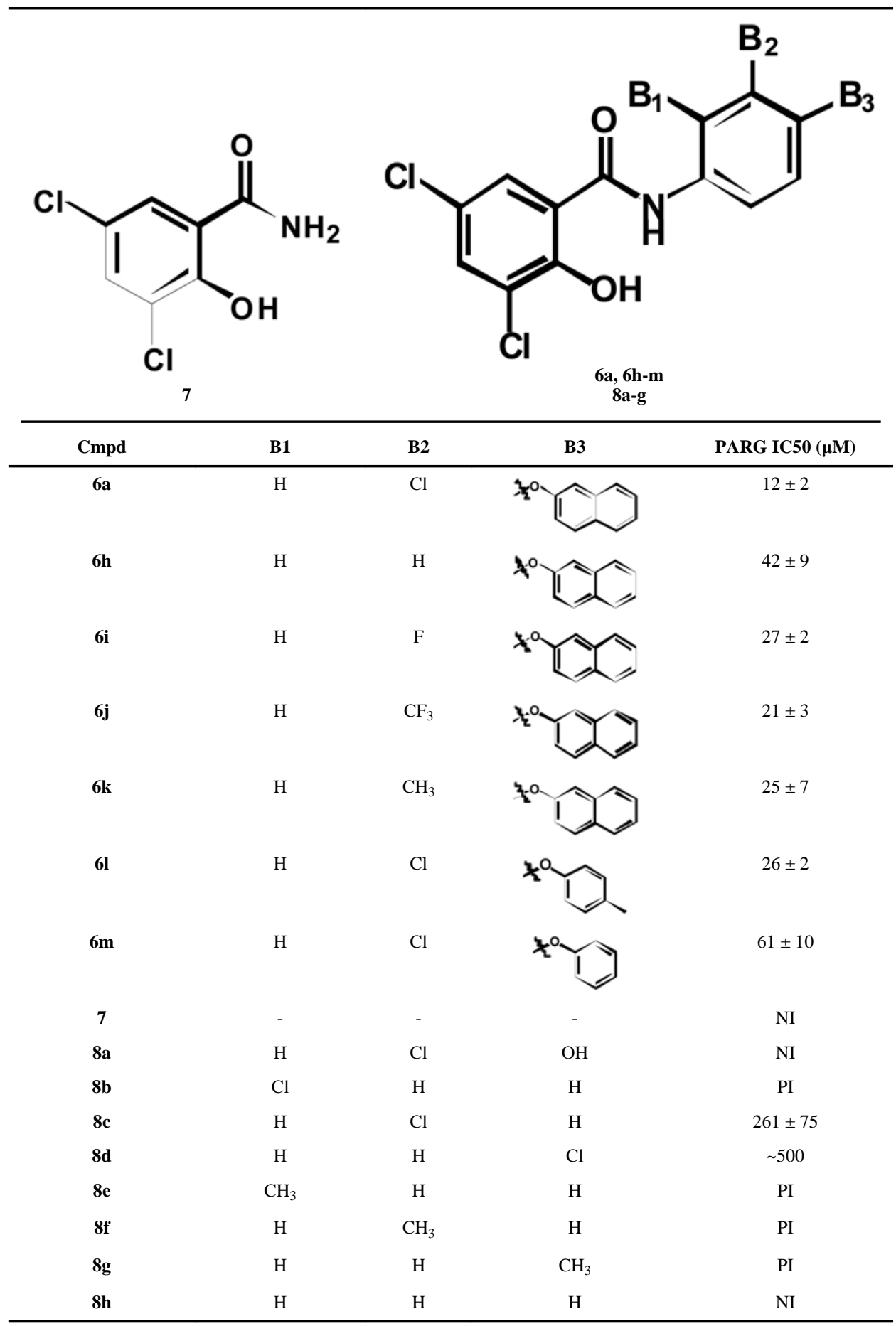

NI (Non inhibitory): inhibition of PARG does not exceed $10 \%$ at 500 $\mu$ M PI (Partially inhibitory): inhibition of PARG is between 10-30\% at $500 \mu \mathrm{M}$ 
Table 5

Cross inhibition with PARP-1

\begin{tabular}{ccc}
\hline Cmpd & PARG IC50 $(\boldsymbol{\mu M})$ & PARP-1 IC50 $(\boldsymbol{\mu M})$ \\
\hline $\mathbf{1 e}$ & $8 \pm 0.6$ & $123 \pm 19$ \\
$\mathbf{1 f}$ & $22 \pm 2$ & $22 \pm 6$ \\
$\mathbf{1 g}$ & $26 \pm 3$ & $78 \pm 14$ \\
$\mathbf{6 a}$ & $12 \pm 2$ & $120 \pm 22$ \\
$\mathbf{6 g}$ & $72 \pm 7$ & $66 \pm 6$ \\
$\mathbf{8 b}$ & $261 \pm 75$ & $\sim 500$ \\
$\mathbf{8 c}$ & $\sim 500$ & $\sim 500$ \\
ADP-HPD & 0.12 & $>1000$ \\
Benzamide $^{\#}$ & $>1000$ & $5.4 \pm 0.4$ \\
\hline * & & \\
See references 30 & & \\
\# See Reference 38 &
\end{tabular}

